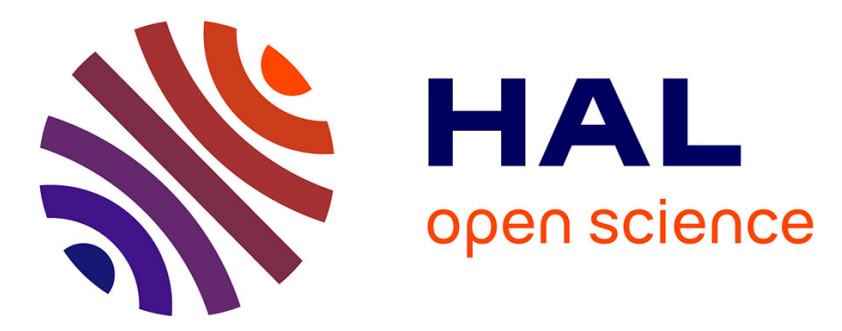

\title{
A combined crystallographic analysis and ab initio calculations to interpret the reactivity of functionalized hexavanadates and their inhibitor potency toward $\mathrm{Na}+/ \mathrm{K}+$-ATPase
}

Xiao M Xu, Nada B Bošnjaković-Pavlović, Mirjana M Čolović, Danijela M Krstić, Vesna M Vasić, Jean-Michel Gillet, Pingfan M Wu, Yongge B Wei, Anne M Spasojević-de Biré

\section{- To cite this version:}

Xiao M Xu, Nada B Bošnjaković-Pavlović, Mirjana M Čolović, Danijela M Krstić, Vesna M Vasić, et al.. A combined crystallographic analysis and ab initio calculations to interpret the reactivity of functionalized hexavanadates and their inhibitor potency toward $\mathrm{Na}+/ \mathrm{K}+$-ATPase. Journal of Inorganic Biochemistry, 2016, 161, pp.27 - 36. 10.1016/j.jinorgbio.2016.04.029 . hal-01385048

\author{
HAL Id: hal-01385048 \\ https://hal.science/hal-01385048
}

Submitted on 24 Sep 2020

HAL is a multi-disciplinary open access archive for the deposit and dissemination of scientific research documents, whether they are published or not. The documents may come from teaching and research institutions in France or abroad, or from public or private research centers.
L'archive ouverte pluridisciplinaire HAL, est destinée au dépôt et à la diffusion de documents scientifiques de niveau recherche, publiés ou non, émanant des établissements d'enseignement et de recherche français ou étrangers, des laboratoires publics ou privés. 


\section{Accepted Manuscript}

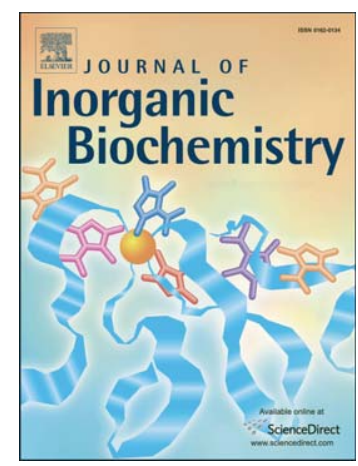

A combined crystallographic analysis and $a b$ initio calculations to interpret the reactivity of functionalized hexavanadates and their inhibitor potency toward $\mathrm{Na}^{+} / \mathrm{K}^{+}$-ATPase

Xiao Xu, Nada Bošnjaković-Pavlović, Mirjana B. Čolović, Danijela Z. Krstić, Vesna M. Vasić, Jean-Michel Gillet, Pingfan Wu, Yongge Wei, Anne Spasojević-de Biré

PII: S0162-0134(16)30114-3

DOI: doi: 10.1016/j.jinorgbio.2016.04.029

Reference: JIB 9987

To appear in: Journal of Inorganic Biochemistry

Received date: $\quad 22$ November 2015

Revised date: $\quad 16$ April 2016

Accepted date: $\quad 25$ April 2016

Please cite this article as: Xiao Xu, Nada Bošnjaković-Pavlović, Mirjana B. Čolović, Danijela Z. Krstić, Vesna M. Vasić, Jean-Michel Gillet, Pingfan Wu, Yongge Wei, Anne Spasojević-de Biré, A combined crystallographic analysis and $a b$ initio calculations to interpret the reactivity of functionalized hexavanadates and their inhibitor potency toward $\mathrm{Na}^{+} / \mathrm{K}^{+}$-ATPase, Journal of Inorganic Biochemistry (2016), doi: 10.1016/j.jinorgbio.2016.04.029

This is a PDF file of an unedited manuscript that has been accepted for publication. As a service to our customers we are providing this early version of the manuscript. The manuscript will undergo copyediting, typesetting, and review of the resulting proof before it is published in its final form. Please note that during the production process errors may be discovered which could affect the content, and all legal disclaimers that apply to the journal pertain. 


\section{A combined crystallographic analysis and $a b$ initio calculations to interpret the reactivity of functionalized hexavanadates and their inhibitor potency toward $\mathrm{Na}^{+} / \mathrm{K}^{+}$-ATPase}

Xiao Xu† ${ }^{\mathrm{a}, \mathrm{b}}$, Nada Bošnjaković-Pavlović $\dagger^{\mathrm{c}}$, Mirjana B. Čolović ${ }^{\mathrm{d}}$, Danijela Z. Krstić* ${ }^{\mathrm{e}}$, Vesna M. Vasić $^{\mathrm{d}}$, Jean-Michel Gillet ${ }^{\mathrm{a}, \mathrm{b}}$, Pingfan $\mathrm{Wu}^{\mathrm{f}}{ }^{\mathrm{f}}$, Yongge Wei ${ }^{\mathrm{g}}$, and Anne Spasojević-de Biré* a,b

${ }^{a}$ Université Paris Saclay, CentraleSupélec, Campus de Châtenay, Grande Voie des Vignes, 92295 Châtenay-

Malabry, France

${ }^{\mathrm{b}}$ CNRS, UMR 8580, Laboratory “Structures Propriétés et Modélisation des Solides" (SPMS), Grande Voie des Vignes, 92295 Châtenay-Malabry, France

${ }^{c}$ Faculty of Physical Chemistry, University of Belgrade, P.O. Box 47, 11001 Belgrade, Serbia

${ }^{\mathrm{d}}$ Department of Physical Chemistry, Vinča Institute of Nuclear science, University of Belgrade, P.O.Box 522,

Belgrade, Serbia

${ }^{\mathrm{e}}$ University School of Medicine, Institute of Medical chemistry, University of Belgrade, Višegradska 26, 11000

Belgrade, Serbia

${ }^{\mathrm{f}}$ Institute of POM-based Materials, The Synergistic Innovation Center of Catalysis Materials of Hubei Province, Hubei University of Technology, 430086 Wuhan, Hubei Province, P. R. China

${ }^{g}$ Department of Chemistry, Tsinghua University, 100084 Beijing, P. R. China

$\uparrow \mathrm{XX}$ and NBP have contributed equally

* authors to whom correspondence should be addressed 


\begin{abstract}
In vitro influence of five synthesized functionalized hexavanadates $\left(\mathrm{V}_{6}\right)$ on commercial porcine cerebral cortex $\mathrm{Na}^{+} / \mathrm{K}^{+}$-ATPase activity has been studied. Dose dependent $\mathrm{Na}^{+} / \mathrm{K}^{+}$ATPase inhibition was obtained for all investigated compounds. Calculated half maximal inhibitory concentration $\mathrm{IC}_{50}$ values, in $\mathrm{mol} / \mathrm{L}$, for $\mathrm{Na}^{+} / \mathrm{K}^{+}$-ATPase were $7.6 \times 10^{-5}, 1.8 \times 10^{-5}$, $2.9 \times 10^{-5}, 5.5 \times 10^{-5}$ for functionalized hexavanadates $\left(\mathrm{V}_{6}\right)$ with tetrabutylammonium (TBA) $\left[\mathrm{V}_{6}-\mathrm{CH}_{3}\right][\mathrm{TBA}]_{2}, \quad\left[\mathrm{~V}_{6}-\mathrm{NO}_{2}\right][\mathrm{TBA}]_{2}, \quad\left[\mathrm{~V}_{6}-\mathrm{OH}\right][\mathrm{TBA}]_{2}$ and $\left[\mathrm{V}_{6}-\mathrm{C}_{3}\right][\mathrm{TBA}]_{2}$ respectively. $\left[\mathrm{V}_{6^{-}}\right.$ $\mathrm{OH}][\mathrm{Na}]_{2}$ inhibited $\mathrm{Na}^{+} / \mathrm{K}^{+}$-ATPase activity up to $30 \%$ at maximal investigated concentration $1 \times 10^{-3} \mathrm{~mol} / \mathrm{L}$. This reactivity has been interpreted using a study of the non-covalent interactions of functionalized hexavanadate hybrids through Cambridge Structural Database (CSD) analysis. Bibliographic searching has led to 18 different structures and 99 contacts. We have observed that $\mathrm{C}-\mathrm{H} \cdots \mathrm{O}$ contacts consolidate the structures. We have also performed density functional theory (DFT) calculations and have determined electrostatic potential values at the molecular surface on a series of functionalized $V_{6}$. These results enlightened their chemical reactivity and their potential biological applications such as the inhibition of the ATPase.
\end{abstract}

Keywords: Functionalized hexavanadate, $\mathrm{Na}^{+} / \mathrm{K}^{+}$-ATPase, inhibition, Cambridge Structural Database, non-covalent interactions

\title{
Short synopsis
}

Five compounds of hexavanadates $\left(\mathrm{V}_{6}\right)$ were synthesized and their inhibitor potency toward $\mathrm{Na}^{+} / \mathrm{K}^{+}$-ATPase was investigated. Investigated hexavanadates showed inhibitory effect on $\mathrm{Na}^{+} / \mathrm{K}^{+}$- ATPase activity. Analysis of noncovalent interactions between $\mathrm{V}_{6}$ and organic part using the Cambridge Structural Database was performed. 


\section{Graphical abstract}

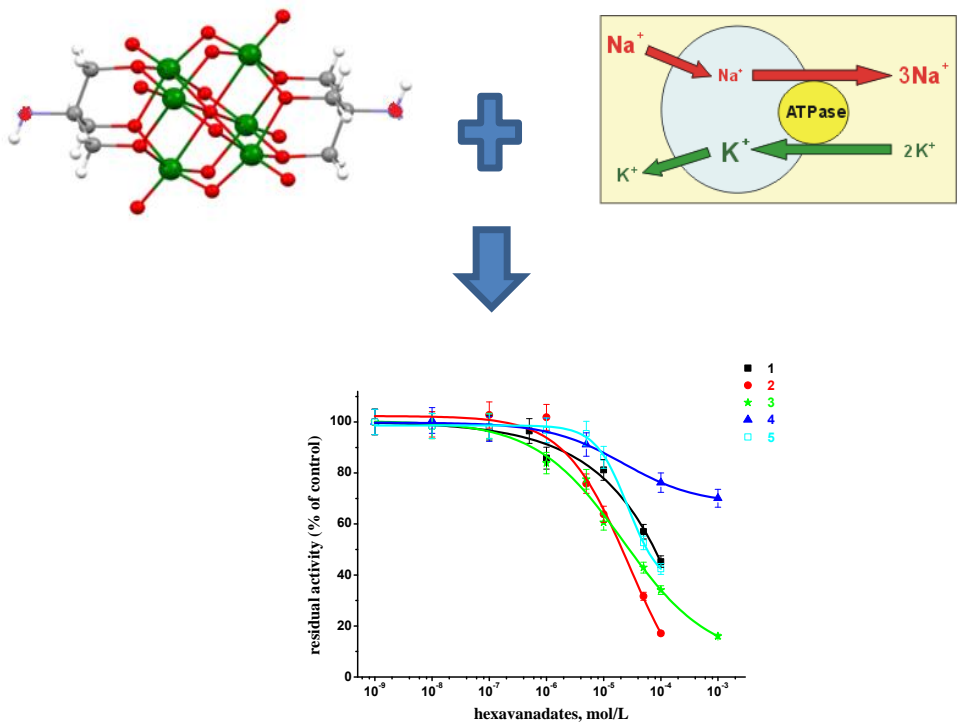




\section{Introduction}

Polyoxovanadates (POVs) are one of the most important series in the large family of polyoxometalate (POMs), due to their wide structure diversity. POVs are a very interesting kind of vanadium-containing compounds due to the fascinating electronic and magnetic properties, various thermodynamically stable redox isomers, and catalytic capabilities [1, 2]. In 1983, M. T. Pope illustrated, that vanadium, in its higher oxidation state, gives many isopolyvanadates ranging from metavanadates chains $\left[\mathrm{VO}^{3-}\right]_{\mathrm{n}}$, to layered oxides $\left[\mathrm{V}_{2} \mathrm{O}_{5}\right]$ and compact polyanions $\left[\mathrm{V}_{10} \mathrm{O}_{28}\right]^{6-}$ [1]. Even polyanionic hollow cages such as $\left[\mathrm{V}_{15} \mathrm{O}_{36}\right]^{5-}$, in which anions are encapsulated, have been reported [2]. Such a rich structural chemistry is due to the ability of vanadium to adopt a variety of coordination geometries, $\left[\mathrm{VO}_{6}\right],\left[\mathrm{VO}_{5}\right],\left[\mathrm{VO}_{4}\right]$ units and different oxidation states $\left(\mathrm{V}^{\mathrm{V}}, \mathrm{V}^{\mathrm{IV}}\right)$. Hexavanadates $\left(\mathrm{V}_{6}\right)$, one of an important series of POVs, exists as inorganic-organic hybrids (Figure 1). After the initial characterization of $\left[\left(\mathrm{C}_{5} \mathrm{Me}_{5}\right) \mathrm{Rh}\right]_{4}\left(\mathrm{~V}_{6} \mathrm{O}_{19}\right)$ by Chae [3] and Hayashi [4,5], a large number of new polyoxovanadates and their related properties were mainly reported by several groups of Müller, Zubieta [8-10], Hill [11,12], Hayashi [13], T. B. Liu [14], Wei [15,16], and Daniel [17] over the last 30 years. Hayashi has described the different species of POV structures such like tetravanadate $\left(\mathrm{V}_{4}\right.$ unit), hexavanadates $\left(\mathrm{V}_{6}\right.$ unit), decavanadate ( $\mathrm{V}_{10}$ unit), dodecavanadate $\left(\mathrm{V}_{12}\right.$ unit), and other heteropolyoxovanadates, lacunary POV, providing a better understanding on the classification of POVs complicated structures [13].

Recently, we found that POVs exhibit potential bioactivities, especially the inhibition of $\mathrm{Na}^{+} / \mathrm{K}^{+}$-ATPase [18]. Dose-dependent inhibition of plasma membrane $\mathrm{Ca}^{2+}$-ATPase (PMCA) and sodium pump by $\mathrm{V}_{10}$ as well as kinetic analysis, is in agreement with previously reported findings that $\mathrm{V}_{10}$ species block the active side of P-type ATPases. Consequently, it affects phosphorylation step in the enzyme cycle of P-type ATPases (sodium and calcium pump) [19]. $\mathrm{Na}^{+} / \mathrm{K}^{+}$-ATPase (sodium pump) belongs to the P-type ATPase family, which are able to utilize the energy of ATP to transport ions against their electrochemical gradient. $\mathrm{Na}^{+} / \mathrm{K}^{+}$-ATPase is a cell membrane located in enzyme and maintaining the high internal $\mathrm{K}^{+}$ and low internal $\mathrm{Na}^{+}$concentrations, characteristic and essential for normal cellular activities of most animal cells [20,21]. The activity of this enzyme is very sensitive to the presence of some metal ions and organic compounds of various structures, especially in the case of some drugs and pesticides [22]. $\mathrm{Na}^{+} / \mathrm{K}^{+}$-ATPase has been chosen due to its key role in normal functioning of most cells of higher eukaryotic organisms [23,24] and in development and progression of different cancers [25], as well as the known influence of POMs on nucleotide- 
dependent enzymes [26-28] and their anti-cancer and anti-viral activity. Investigation of the POMs interactions with peptides or proteins, which play a fundamental role in biological systems, has been a subject of growing interest in recent years [29]. It was reported that $V_{10}$ is the major protein-bound species of vanadium and has a stronger inhibitory effect on various enzymes, when compared to other vanadate oligomers [30]. $\mathrm{V}_{10}$ studies include also the possibility of its use as a tool in the understanding of the transducing chemical energy into conformational energy for $\mathrm{Ca}^{2+}$ transport by $\mathrm{Ca}^{2+}$-ATPase [31] as well as molecular mechanism of muscle contraction [32]. Inhibitions of several ATPases such as P-type ATPases, ABC-ATPases and ribonucleases by $V_{10}$ suggest that $V_{10}$ interactions with these proteins are probably favored by the existence of an ATP binding site [28]. More recently the exceptional biological activity of $\mathrm{V}_{10}$ has been reviewed by Aureliano [33]. These studies illustrate the importance of the noncovalent interactions between vanadate species and peptides. It is clear that vanadate interacts strongly with positively charged proteins. At a molecular level, the mechanism of action is played via noncovalent interactions between the $\mathrm{V}_{10}$ anion and the biological target [34,35]. This information could be useful for understanding the potential reactivity of $\mathrm{V}_{6}$ hybrids (Figure 1). Additionally, $\mathrm{V}_{18}$ presents antitumor activity inhibiting the growth and proliferation of human cancer cells and has a low toxicity on human normal cells in vitro [36]. The mechanism for the antitumor effect of polyoxomolybdate has been established; it concerns a single electron reduction oxidation cycle in isopolymolybdates [37-39]. According to this hypothesis, the inhibitory activity of POMs on tumor cells is relevant to the oxidation reduction ability: the stronger the oxidation capability, the higher the inhibitory effect on tumor cells.

From a geometric point of view, the $\left[\mathrm{V}_{6} \mathrm{O}_{19}\right]^{2-}$ ( simplified as $\mathrm{V}_{6}$ ) anion is represented in Figure 1a. According to their vanadium coordination, the oxygen atoms could be classified as follows. Four types of oxygen atoms are involved in this anion: $\mathrm{O} 1 \mathrm{x}$ - bonded to only one vanadium atom; $\mathrm{O} 2 \mathrm{x}$ - shared between two vanadium atoms; $\mathrm{O} 3 \mathrm{x}$ - connected with two vanadium atoms and organic ligand; O6x - have a six-fold coordination of vanadium atoms. Oxygen atoms of $\mathrm{a} \mathrm{V}_{6}$ anion are attractive sites, and therefore can form intermolecular hydrogen bonds. Many weak hydrogen bonds are found between $\mathrm{V}_{6}$ anions and organic segments. The statistical analysis of these non-covalent interactions between $\mathrm{V}_{6}$ anion and organic segments using the Cambridge Structural Data Base (CSD) can provide structural evidence for the biological role of the $\mathrm{V}_{6}$ anion. Crystal structures of the title compounds are stabilized by an extensive C-H...O hydrogen bonding network, which involves the $\mathrm{V}_{6}$ anions 
and organic segments. Hydrogen bonds and their environment have a well-defined geometry in the crystalline state. CSD provides a large amount of experimental data that allows hydrogen bonds geometries to be analyzed with good statistics [41]. Therefore, CSD is a major source of knowledge on intermolecular interactions of all types. A major contribution of CSD analysis has been the identification of weak hydrogen bonds such as $\mathrm{CH}^{\cdots} \mathrm{O}$ or $\mathrm{CH}^{\cdots} \pi$ [42-44].

In this study, we have synthesized five $\mathrm{V}_{6}$ to investigate the in vitro effect of $\mathrm{V}_{6}$ on commercial porcine cerebral cortex $\mathrm{Na}^{+} / \mathrm{K}^{+}$-ATPase activity. In order to understand the obtained results, we have retrieved the $\mathrm{V}_{6}$ based compound structures from the CSD, and determined the intermolecular interactions between $\mathrm{V}_{6}$ oxygen atoms and the proton donor. We have also determined theoretical electrostatic potential (EP) from ab initio calculations.

\section{Material and methods}

\subsection{Synthesis of $\mathrm{V}_{6}$ compounds}

Preparation of $\left[\mathbf{V}_{6}-\mathbf{C H}_{3}\right][\mathbf{T B A}]_{2}$ (TBA tetrabutylammonium) (compound $\mathbf{1}$ ). $\mathbf{1}$ has been synthesized according to the route described by Chen et al [8]. Preparation of [ $\mathbf{V}_{\mathbf{6}^{-}}$ $\left.\mathbf{N O}_{2}\right][\text { TBA }]_{2}$ (compound 2). 2 has been synthesized according to the route described by Chen et al $[48 \mathrm{f}]$. Preparation of $\left[\mathbf{V}_{\mathbf{6}}-\mathbf{O H}\right][\mathbf{T B A}]_{2}$ (compound $\mathbf{3}$ ). $\mathbf{3}$ has been synthesized according to the route described by Wu et al [45]. Preparation of $\left[\mathbf{V}_{\mathbf{6}}-\mathbf{O H}\right][\mathbf{N a}]_{2}$ (compound 4 ). 4 has been synthesized according to the route described by $\mathrm{Wu}$ et al [45]. Preparation of [ $\mathbf{V}_{\mathbf{6}^{-}}$ $\left.\mathbf{C}_{3}\right][\text { TBA }]_{2}$ (compound $\mathbf{5}$ ). $\mathbf{5}$ has been obtained according to the route described by Wu et al [46].

\subsection{Preparation of $\mathrm{V}_{6}$ solutions}

Stock solutions $(0.1 \mathrm{~mol} / \mathrm{L})$ of $\mathbf{1}, \mathbf{2}, \mathbf{3}$ and 5 were prepared by solving the solid compounds in DMSO, while 4 stock solutions was prepared in aqueous solution. Working solutions were prepared daily by water dilution of the stock solutions to the desired concentrations, shortly before use.

\section{3. $\mathrm{Na}^{+} / \mathrm{K}^{+}$-ATPase assay}

The standard assay medium for investigation of $\mathrm{Na}^{+} / \mathrm{K}^{+}$-ATPase activity contains (in mmol/L): 50 Tris-HCl (pH 7.4), $100 \mathrm{NaCl}, 20 \mathrm{KCl}, 5 \mathrm{MgCl}_{2}, 2$ ATP and $290 \mathrm{mg} / \mathrm{L}$ 
commercially available porcine cerebral cortex proteins in a final volume of $200 \mu \mathrm{L}$. After pre-incubation for $10 \mathrm{~min}$ at $37^{\circ} \mathrm{C}$ and control of the appropriate concentration of the investigated $\mathrm{V}_{6}$ compounds, the reaction was initiated by addition of ATP and stopped after 20 mins by adding $22 \mu \mathrm{l}$ of $3 \mathrm{~mol} / \mathrm{l}$ ice cold $\mathrm{HClO}_{4}$ and immediate cooling on ice. Final DMSO volume fraction in the incubation medium does not exceed $1 \%$. The released inorganic phosphate group $\left(\mathrm{P}_{\mathrm{i}}\right)$ liberated from the hydrolysis of ATP was determined by a modified spectrophotometric method [47]. Spectrophotometric measurements were performed on a Perkin Elmer Lambda 35 UV VIS spectrophotometer. Results are expressed as mean percentage enzyme activity compared to the corresponding control value \pm S.E.M. (standard error of mean) of two independent experiments done in triplicate.

\subsection{CSD analysis}

We have investigated the interactions depending on the oxygen types of $\mathrm{V}_{6}, \mathrm{O} 1 \mathrm{x}$ and $\mathrm{O} 2 \mathrm{x}$, which are on the surface of the molecules. We have focused on the arm-like functionalized $\mathrm{V}_{6}$ anion with two symmetrical tripodal ligands, which are listed in Table 1. Different structures have been found to contain $\mathrm{V}_{6}$ anion, leading to 99 intermolecular contacts, which are shorter than the sum of van der Waals radii. In order to avoid crystal structure low quality, the $\mathrm{R}$ factor was required to be less than 10 . These interactions belong to the 18 structures for which the hydrogen bonds have been localized [48]. For each interaction, depending on the oxygen type $\mathrm{O} 1 \mathrm{x}$ and $\mathrm{O} 2 \mathrm{x}$, we have calculated the $\mathrm{C}-\mathrm{H} \ldots \mathrm{O}$ distance and angle. Moreover, we have retrieved protonated $\mathrm{V}_{6}$ (Table 1) and $\mathrm{V}_{6}$ based compounds where more than six external oxygen atoms are bridged with organic ligands [49], in order to analyze the reactivity of external oxygen atoms (Table 2).

\subsection{Computational details}

DFT calculations were performed with Gaussian 09 (EM64L-G09RevC.01) [Frisch, 2010]. Hybrid functionals, which include a mixture of Hartree-Fock exchange with DFT exchange-correlation have been employed (B3LYP: [Becke, 1993]; M06/M06-2X, [Zhao, 2008]. Atomic coordinates of $\left[\mathrm{V}_{10} \mathrm{O}_{28}\right]^{6-}[34],\left[\mathrm{V}_{6} \mathrm{OH}\right]^{2-}$ (compound 3 and 4) [53], and [V6$\mathrm{C} 3]^{2-}$ (compound $\mathbf{1}$ and 5) [53] are obtained from the corresponding high resolution X-ray diffraction experimental nuclei positions. Geometric optimization was carried out. Atomic coordinates of compound $\mathbf{2}$ have been obtained from CSD; the geometry has been optimized 
by $M 06 / 6-31+G(d, p)$ quantum chemistry model. The computed densities have converged with cc-pVTZ basic set.

\section{Results and discussion}

\subsection{In vitro influence of $\mathrm{V}_{6}$ compounds on $\mathrm{Na}^{+} / \mathrm{K}^{+}$-ATPase activity}

The influence of the five synthesized $\mathrm{V}_{6}$ compounds (Table 3 ) on commercial porcine cerebral cortex $\mathrm{Na}^{+} / \mathrm{K}^{+}$-ATPase activity has been investigated by in vitro exposure to the enzyme in the concentration range from $1 \times 10^{-9}$ to $1 \times 10^{-3} \mathrm{~mol} / \mathrm{L}$. The results show, in all cases, that increasing concentrations of the investigated compounds induce inhibition of enzymatic activity in a concentration-dependent manner (Figure 2). The experimental dependence of the enzyme activity, expressed as a percentage of the control value (obtained without inhibitor), on inhibitor concentration fits a sigmoidal function (Figure 2).

The inhibition parameters ( $\mathrm{IC}_{50}$ values), defined as the concentration of investigated compound with capability to inhibit $50 \%$ of the enzyme after given exposure time, were determined using the sigmoidal fit and summarized in Table 3. The obtained results demonstrate that the inhibitory effect on $\mathrm{Na}^{+} / \mathrm{K}^{+}$-ATPase activity was rated as compounds $\mathbf{2}>$ $\mathbf{3}>\mathbf{5}>\mathbf{1}>\mathbf{4}$. Actually, the most potent inhibitor is compound $2\left(\mathrm{IC}_{50}=(1.8 \pm 0.5) \times 10^{-5}\right.$ mol/L), while the compounds 3,5 and $\mathbf{1}$ are several times weaker inhibitors of $\mathrm{Na}^{+} / \mathrm{K}^{+}-$ ATPase, which induced half of maximal enzyme activity (control) at concentrations (in $\mathrm{mol} / \mathrm{L})$ of $(2.9 \pm 0.3) \times 10^{-5},(5.5 \pm 0.3) \times 10^{-5},(7.6 \pm 0.5) \times 10^{-5}$, respectively. The enzyme is significantly less sensitive toward 4, i.e. half of maximum enzyme inhibition was not reached at the highest investigated concentration, $1 \times 10^{-3} \mathrm{~mol} / \mathrm{L}$.

The obtained results (Figure 2 and Table 3) are in agreement with previously reported concentration-dependent inhibitory effect of polyoxovanadates on synaptic plasma membrane and purified porcine cerebral cortex $\mathrm{Na}^{+} / \mathrm{K}^{+}$-ATPase [18] as well as several nucleotidedependent enzymes [26,27]. However, $V_{10}$ has been observed around ten times more potent inhibitor of the purified enzyme [18] compared with investigated $V_{6}(\mathbf{1}, \mathbf{2}, \mathbf{3}$ and $\mathbf{5})$.

The key factors, which could explain the interaction between $V_{6}$ and $V_{10}$ compounds and $\mathrm{Na}+\mathrm{K}+$-ATPase are: i) the size of the inhibitor (consistent with the enzyme pocket); ii) the EP express by the inhibitor (in complementary with the EP express by enzyme pocket); iii) the possibility of the inhibitor to build hydrogen bonds or non-covalent interactions with amino acids of the enzyme. In this case, the inhibitor is the functionalized $V_{6}$ anion, the 
counter ion (TBA or $\mathrm{Na}^{+}$) is necessary to stabilize the $\mathrm{V}_{6}$, but in solution the functionalized $\mathrm{V}_{6}$ anion is supposed to be isolated. The observed differences between compounds $\mathbf{3}$ and $\mathbf{4}$ could be assigned to an additional effect due to the cation. The size of the $V_{6}$ series could be modeled by the longest distance between two opposite atoms of the organic arm of the functionalized $\mathrm{V}_{6}$ compound. Correlation between the size of the compound and the inhibition activity could not be established.

EP values at the molecular surface of the functionalized V6 series have been determined and plotted (Figure 3). EP can be used as a tool for predicting chemical reactivity, especially for non-covalent interactions. EP values are the most negative in the vicinity of the three oxygen atoms defining the yellow triangle (Figure 3, left column). This provides a predictable pattern for non-covalent interactions and points out the probable chemical reactivity sites. In this type of functionalized V6 compounds, under a proper condition, O1x and $\mathrm{O} 2 \mathrm{x}$ could act as potential reaction sites $[54,55,49 \mathrm{f}]$. In order to graphically exhibit the intermolecular charge transfer in a better way, between $\mathrm{V}_{6}$ core and the organic ligand, electrostatic potentials are mapped as isovalue surfaces at \pm 0.75 e $\mathrm{A}-1$ (Figure 3 right column). The red part (negative) is localized around the $\mathrm{V}_{6}$ core, which corresponds to the most nucleophilic regions, while the blue part (positive) is concentrated over the organic ligand and represents the most electrophilic regions. This property reveals the most important features of these hybrid compounds. Figure 4 represents the evolution of the EP minimum, the EP maximum and the difference between these two values. Clearly, a very negative value $\left(\mathrm{V}_{10}\right)$ implies a better inhibition. Nevertheless, it is difficult to understand the inhibitor behavior inside the functionalized V6 series from these EP values. The qualitative observation of the EP (Figure 3, right column) indicates that $\left[\mathrm{V}_{6}-\mathrm{NO}_{2}\right][\mathrm{TBA}]_{2}$, (compound 2) and in a less extent the $\left[\mathrm{V}_{6}-\mathrm{OH}\right][\mathrm{TBA}]_{2}$ (compound 3, cation TBA) presents additional negative regions. This could be help explain why these compounds are good inhibitor candidates.

Ziegler et al [56] demonstrated by ab initio quantum computation and biochemical investigations, that an increasing positive charge on the vanadyl group increases the inhibition potency of the vanadyl complex on alkaline phosphatase. Different bioactivities for the functionalized $\mathrm{V}_{6}$ have to be discussed where is the specific binding sites on the enzyme. It is then essential to investigate the possibility of $\mathrm{V}_{6}$ core to built hydrogen bonds, and the possibilities of functionalized $\mathrm{V}_{6}$ to have complementary electrostatic potential interactions with the interaction enzyme pocket site. Following the work of Ziegler [56], Mulliken charges belonging to the $\mathrm{V}-\mathrm{O}$ group have been explored (table 3). We found $\mathbf{2}$ has the most 
nucleophilic oxygen on $\mathrm{O} 1 \mathrm{x}$. We observe that the most charged $\mathrm{V}-\mathrm{O} 1 \mathrm{x}$ bonds belong to 2 . The specific behavior of $\mathbf{2}$ is clearer when calculating average Mulliken charges over the three bonds (V-O1x, V-O2x and V-O3x), shown in table 3. Our results are in agreement with those of Ziegler where the more positive V-O bonds allow the complex to bind more tightly to the enzyme [56]. Holtz et al, [57] has studied the co-crystallization of alkaline phosphatase complexed with vanadate. They have established the binding site where the vanadate ligand is a modified serine. Previous protein structures show that $\mathrm{V}_{10}$ is bonded via hydrogen bond with acid phosphatase [58] and tyrosine kinase [59]. In these two protein structures, $\mathrm{V}_{10}$ anion is linked to enzymes through the amino acids: histidine (His), lysine (Lys), asparagines (Asn), arginine (Arg), moieties which are positively charged or present polar chains.

Therefore, as demonstrated by our ab initio calculations and in agreement with the literature, $\mathrm{V}_{6}$ and $\mathrm{V}_{10}$ core exhibit negative charge, which corresponds to nucleophilic molecular region and in contrary, the organic ligand corresponds to an electrophilic molecular region.

\section{2. $\mathrm{V}_{6}$ binding}

In previous studies [34, 35], we have predicted the preferential non-covalent interactions with the different oxygen atoms of the $\mathrm{V}_{10}$ anion in order to explain and predict the behaviour of those species in case of a reaction with protons or cationic groups. A similar analysis has been done on $\mathrm{V}_{6}$ compounds. The nucleophilic oxygen atoms, which are available on the surface of $\mathrm{V}_{6}$ as hydrogen bond acceptor, interact with oxygen, nitrogen or carbon atoms of organic moieties as hydrogen donor in order to form hydrogen bonds, such as $\mathrm{O}_{\mathrm{V} 6} \cdots \mathrm{HO}, \mathrm{O}_{\mathrm{V} 6} \cdots \mathrm{HN}, \mathrm{O}_{\mathrm{V} 6} \cdots \mathrm{HC}$. The carbon atoms of the ligands interact with the oxygen atoms of $\mathrm{V}_{6}$ through $\mathrm{O}_{\mathrm{V} 6} \cdots \mathrm{HC}$ hydrogen bonds. From the structures containing the $\left[\mathrm{V}_{6} \mathrm{O}_{19}\right]^{2-}$, we have chosen the 18 crystalline structures with six bridged organic ligands (Table 1). In all 18 structures, we have found weak $\mathrm{C}-\mathrm{H}^{\cdots} \mathrm{O}$ bonds due to the fact that $\mathrm{V}_{6}$ anion is stabilized with large non-polar chain through the network of weak $\mathrm{C}-\mathrm{H}^{\cdots} \mathrm{O}$ bonds. Both $\mathrm{O} 1 \mathrm{x}$ and $\mathrm{O} 2 \mathrm{x}$ atoms build weak $\mathrm{C}-\mathrm{H}^{\cdots} \mathrm{O}$ bonds. The geometry of $\mathrm{C}-\mathrm{H}^{\cdots} \mathrm{O}$ interactions have been analyzed using the 99 identified non-bonding interactions. Figure 5 and 6 show the results of the CSD search of the $\mathrm{C}-\mathrm{H}^{\cdots} \mathrm{O}$ distances and angles distribution for all intermolecular interactions. In term of angularity, all these interactions follow the trend expected for hydrogen bonds; namely the $\mathrm{C}-\mathrm{H}^{\cdots} \mathrm{O}$ angle opens up as the distance between donor and acceptor increases. C- 
$\mathrm{H}^{\cdots} \mathrm{O}$ interactions are mainly at long distance $2.4-2.8 \AA$ and angle from $120-160^{\circ}$ included in an ellipsoid drawn on Figure 5.

The variation in bond distance and angle for $\mathrm{C}-\mathrm{H}^{\cdots} \mathrm{O}$ interaction (Figure 5 and Figure 6) reflects the different types of interaction: stronger bond, at shorter distances and higher angle binding with oxygen atoms $\mathrm{O} 2 \mathrm{x}$ and weaker bond mainly binding with $\mathrm{O} 1 \mathrm{x}$. The percentage of interaction for which $\mathrm{d}_{\mathrm{H}} \ldots \mathrm{O}<2.5 \AA$ is $39 \%$ for $\mathrm{O} 2$ (respectively $30 \%$ for O1x). It indicates that oxygen atoms $\mathrm{O} 2 \mathrm{x}$ is more reactive than oxygen atoms $\mathrm{O} 1 \mathrm{x}$. Therefore, we can confirm that the protonation sites in the cage are oxygen atoms of type O2x. This observation is in agreement with theoretical calculation [60], and our experimental "Atom In Molecules" (AIM) charges, where we have found that $\mathrm{O} 2$ atoms are more reactive than $\mathrm{O} 1$ [53].

\subsection{Localization of protonation basic sites on $\mathrm{V}_{6}$ core}

In order to obtain a quantitative determination of the relative activity and the protonation sites in $\mathrm{V}_{6}$ anion, we have used the protonated hexavanadate from Table 1 (i.e. PAGSOF, PAGSUL, PAGTAS, KURBOO, KURBUU) and hexavanadate based compounds where more than six oxygen atoms are bridged with organic ligands (Table 2). The hydrogen positions in protonated $\mathrm{V}_{6}$ are located only in few compounds. The protonation site on all reported $\mathrm{V}_{6}$ compounds, is at $\mathrm{O} 2 \mathrm{x}$ bridging oxygen. Oxygen atoms $\mathrm{O} 1 \mathrm{x}$ are not connected with organic ligands. The main protonation site for the protonated $\mathrm{V}_{6}$ anion is oxygen atom $\mathrm{O} 2 \mathrm{x}$ and the main atoms for connection with organic parts is $\mathrm{O} 2 \mathrm{x}$. These results suggest that atom $\mathrm{O} 2 \mathrm{x}$ is more reactive than atom $\mathrm{O} 1 \mathrm{x}$. This is in agreement with previous report on theoretical electrostatic potential of $a$ functionalized $\mathrm{V}_{6}$ $\left(\mathrm{Bu}_{4} \mathrm{~N}\right)_{2}\left[\left\{\mathrm{FcC}(\mathrm{O}) \mathrm{NHC}\left(\mathrm{CH}_{2} \mathrm{O}\right)_{3}\right\}_{2} \mathrm{~V}_{6} \mathrm{O}_{13}\right]$ [53]. It was found that oxygen charges are O6x ($1.11)<\mathrm{O} 3 \mathrm{x}(-0.74)<\mathrm{O} 2 \mathrm{x}(-0.68)<\mathrm{O} 1 \mathrm{x}(-0.54)$.

Protonation basic sites of $\mathrm{V}_{6}$ core have been identified as the doubly bridging oxygen atoms $(\mathrm{O} 2 \mathrm{x})$, establishing these as more nucleophilicbasic than the mono-coordinate oxygen atoms $(\mathrm{O} 1 \mathrm{x})$.

\section{Conclusion}

Throughout this work, we have studied the reactivity of functionalized hexavanadates $\mathrm{V}_{6}$. It provides evidence of the oxygen atom type influence on the hydrogen bonding geometry. Analysis of non-covalent interactions between $\mathrm{V}_{6}$ and organic part using CSD show 
that $\mathrm{O} 2 \mathrm{x}$ oxygen atoms are more reactive than $\mathrm{O} 1 \mathrm{x}$. We confirm that the protonation sites in the cage are oxygen atoms of type $\mathrm{O} 2 \mathrm{x}$. Increasing concentrations of the synthetized hexavanadates induce the inhibition of $\mathrm{Na}^{+} / \mathrm{K}^{+}$-ATPase activity in a concentration-dependent manner in all cases. $\mathrm{IC}_{50}$ values for each investigated hexavanadate (except 4 ) were the same order of magnitude (in the range $1 \times 10^{-5}-1 \times 10^{-4} \mathrm{~mol} / \mathrm{L}$ ). The obtained results demonstrate that the most potent inhibitor is compound $\left[\mathrm{V}_{6}-\mathrm{NO}_{2}\right][\mathrm{TBA}]_{2},\left(\mathrm{IC}_{50}=(1.8 \pm 0.5) \times 10^{-5} \mathrm{~mol} / \mathrm{L}\right)$. Qualitative observation of the EP indicates that $\left[\mathrm{V}_{6}-\mathrm{NO}_{2}\right][\mathrm{TBA}]_{2}$ and in a less extent $\left[\mathrm{V}_{6^{-}}\right.$ $\mathrm{OH}][\mathrm{TBA}]_{2}$ presents additional negative regions. We observe from ab initio calculations that $\left[\mathrm{V}_{6}-\mathrm{NO}_{2}\right][\mathrm{TBA}]_{2}$ has the most nucleophilic sites on "O2x", and it coincides that it has the most effective inhibitor among 1-5. This could be the reason why these compounds could be the good inhibitors.

Table of Abbreviations

\begin{tabular}{|l|l|}
\hline Abbreviation & Meaning \\
\hline A & Acceptor \\
\hline AIM & Atom In Molecules \\
\hline ARG & Arginine \\
\hline ATPase & Adenosine TriPhosphatase \\
\hline CSD & Cambridge Structural Database \\
\hline DFT & Density Functional theory \\
\hline EP & Electrostatic Potential \\
\hline HIS & Histidine \\
\hline IC $\mathbf{5 0}$ values & Half maximal inhibitory concentration values \\
\hline LYS & Lysine \\
\hline NCI & Non-Covalent Interactions \\
\hline O1x & Oxygen atom bonded to only one vanadium atom \\
\hline O2x & Oxygen atom shared between two vanadium atoms \\
\hline O3x & \\
\hline
\end{tabular}




\begin{tabular}{|l|l|}
\hline O6x & Oxygen atom with a six-fold coordination with vanadium atoms \\
\hline $\mathbf{P}_{\mathbf{i}}$ & Inorganic phosphate group \\
\hline PMCA & Plasma membrane $\mathrm{Ca}^{2+}$-ATPase \\
\hline POMs & Polyoxometalates \\
\hline POVs & Polyoxovanadates \\
\hline SEM & standard error of mean \\
\hline TBA & Tetrabutylammonium \\
\hline $\mathbf{V}_{4}$ & Tetravanadate \\
\hline $\mathbf{V}_{\mathbf{6}}$ & Hexavanadate \\
\hline $\mathbf{V}_{\mathbf{1 0}}$ & Decavanadate \\
\hline $\mathbf{V}_{\mathbf{1 2}}$ & Dodecavanadate \\
\hline
\end{tabular}

\section{Acknowledgements}

XX thanks CSC for scholarship. NBP thanks CentraleSupelec for invited associated professor position. NBP would like to thank the Ministry of Education, Science and Technological Development of the Republic of Serbia for financial support (Project No OI 172043). MBČ, DZK and VMV are grateful to the Ministry of Education, Science and Technological Development of the Republic of Serbia for the financial support (Project No 172023). Theoretical calculations have been made on the computing meso-center of CentraleSupelec.

\section{Highlights}

- Functionalized hexavanadates $\left(\mathrm{V}_{6}\right)$ inhibit $\mathrm{Na}^{+} / \mathrm{K}^{+}$-ATPase.

- $\left[\mathrm{V}_{6}-\mathrm{OH}\right][\mathrm{Na}]_{2}$ inhibited $\mathrm{Na}^{+} / \mathrm{K}^{+}$-ATPase activity up to $30 \%$ at max. investigated concentration.

- The $\mathrm{O} 2 \mathrm{x}$ bridged oxygen atoms are more reactive than $\mathrm{O} 1 \mathrm{x}$ terminal oxygen.

- The protonation sites in the cage are oxygen atoms of type $\mathrm{O} 2 \mathrm{x}$.

- The most charged V-O1x bond belongs to $\left[\mathrm{V}_{6}-\mathrm{NO}_{2}\right][\mathrm{TBA}]_{2} \mathrm{TBA}$ (tetrabutylammonium). 


\section{References}

[1] M.T. Pope, Heteropoly and Isopoly Oxometalates. Berlin: Springer; 1983.

[2] M.T. Pope, A. Müller, Polyoxometalate Chemistry: An Old Field with New Dimensions in Several Disciplines, Angew. Chem. Int. Ed. Engl. 30 (1991) 34-48.

[3] H.K. Chae, G. Walter, V. Klemperer, W. Day, Organometal hydroxide route to $\left[\left(\mathrm{C}_{5} \mathrm{Me}_{5}\right) \mathrm{Rh}\right]_{4}\left(\mathrm{~V}_{6} \mathrm{O}_{19}\right)$, Inorg. Chem. 28 (1989) 1423-1424.

[6] Y. Hayashi, Y. Ozawa, K. Isobe, The First "Vanadate Hexamer" Capped by Four Pentamethylcyclopentadienyl-rhodium or -iridium Groups, Chem. Lett. 18 (1989) 425426.

[7] Y. Hayashi, Y. Ozawa, K. Isobe, Site-selective oxygen exchange and substitution of organometallic groups in an amphiphilic quadruple-cubane-type cluster. Synthesis and molecular structure of $\left[\left(\mathrm{MCp}^{*}\right) 4 \mathrm{~V}_{6} \mathrm{O}_{19}\right](\mathrm{M}=$ rhodium, iridium $)$, Inorg. Chem. 30 (1991) 1025-1033.

[8] Q. Chen, D. P. Goshorn, C.P. Scholes, X. L. Tan, J. Zubieta, Coordination compounds of polyoxovanadates with a hexametalate core. Chemical and structural characterization of $\left[\mathrm{VV}_{6} \mathrm{O}_{13}\left[\left(\mathrm{OCH}_{2}\right) 3 \mathrm{CR}\right]_{2}\right]^{2-},\left[\mathrm{VV}_{6} \mathrm{O}_{11}(\mathrm{OH})_{2}\left[\left(\mathrm{OCH}_{2}\right) 3 \mathrm{CR}\right]_{2}\right]$ [VIV4VV $\left.2 \mathrm{O}_{9}(\mathrm{OH})_{4}\left[\left(\mathrm{OCH}_{2}\right) 3 \mathrm{CR}\right]_{2}\right]^{2-}$, and $\left.\left.\left[\mathrm{VIV}_{6} \mathrm{O}_{7}(\mathrm{OH})_{6}\right]\left(\mathrm{OCH}_{2}\right) 3 \mathrm{CR}\right]_{2}\right]^{2-}$, J. Am. Chem. Soc. 114 (1992) 4667-468.

[9] Q. Chen, J. Zubieta, Synthesis and structural characterization of a polyoxovanadate coordination complex with a hexametalate core: [(n$\left.\left.\mathrm{C}_{4} \mathrm{H}_{9}\right) 4 \mathrm{~N}\right]_{2}\left[\mathrm{~V}_{6} \mathrm{O}_{13}\left\{\mathrm{O}_{2} \mathrm{NC}\left(\mathrm{CH}_{2} \mathrm{O}\right)_{3}\right\}_{2}\right]$, Inorg. Chem.29 (1990) 1456-1458.

[10] Q. Chen, J. Zubieta, A novel hexavanadate core: synthesis and structure of the mixed valence cluster $\left[\mathrm{V}_{6} \mathrm{O}_{8}\left\{\left(\mathrm{OCH}_{2}\right)_{3} \mathrm{CEt}\right\} 2\left\{\left(\mathrm{OCH}_{2}\right)_{2} \mathrm{C}\left(\mathrm{CH}_{2} \mathrm{OH}\right)(\mathrm{Et})\right\}_{4}\right]^{2-}$ and a comparison with the hexametallate core of $\left[\mathrm{V}_{6} \mathrm{O}_{13}(\mathrm{OMe}) 3\left\{\left(\mathrm{OCH}_{2}\right) 3 \mathrm{CCH}_{2} \mathrm{OH}\right\}\right]^{2-}$, J. Chem. Soc. Chem. Commun. (1993) 1180-1182.

[11] J. W. Han, K.I. Hardcastle, C. L. Hill, Redox-Active Coordination Polymers from Esterified Hexavanadate Units and Divalent Metal Cations, Eur. J.Inorg. Chem. 13 (2006) 2598-2603.

[12] J.W. Han, C.L. Hill, A coordination network that catalyzes $\mathrm{O}_{2}$ based oxidations, J. Am. Chem. Soc.129 (2007) 15094-15095. 
[13] Y. Hayashi, Hetero and Lacunary Polyoxovanadate Chemistry: Synthesis, Reactivity and Structural Aspects, Coord. Chem. Rev.255 (2011) 2270-2280.

[14] L. Ma, S. Liu, J. Zubieta, Synthesis and characterization of a trinuclear polyoxomolybdate containing a reactive $\left[\mathrm{MoO}_{3}\right]$ unit, $[(\mathrm{n}$ $\left.\left.\mathrm{C}_{4} \mathrm{H}_{9}\right)_{4} \mathrm{~N}\right]_{2}\left[\mathrm{Mo}_{3} \mathrm{O}_{7}\left(\mathrm{CH}_{3} \mathrm{C}\left(\mathrm{CH}_{2} \mathrm{O}\right)_{3}\right)_{2}\right]$, and its conversion to the methoxy derivative [(n$\left.\left.\mathrm{C}_{4} \mathrm{H}_{9}\right)_{4} \mathrm{~N}\right]\left[\mathrm{Mo}_{3} \mathrm{O}_{6}\left(\mathrm{OCH}_{3}\right)\left(\mathrm{CH}_{3} \mathrm{C}\left(\mathrm{CH}_{2} \mathrm{O}\right)_{3}\right)_{2}\right]$, Inorg. Chem. 28 (1989) 175-177.

[15] P. Yin, Wu Pingfan, X. Zicheng, D. Li,' E. Bitterlich,' J. Zhang,' P. Cheng,' D.V. Vezenov' T. Liu, Y. Wei, A Double-Tailed Fluorescent Surfactant with a Hexavanadate Cluster as the Head Group, Angew. Chem. Int . Ed.50 (2011) 2521-2525.

[16] P. Wu, Z. Xiao, J. Zhang, J. Hao, J. Chen, P. Yin, Y. Wei, Y. DMAP-catalyzed esterification of pentaerythritol-derivatized POMs: a new route for the functionalization of polyoxometalates, Chem. Commun.47 (2011) 5557-5559.

[17] C. Daniel, H. Hartl, Neutral and Cationic $\mathrm{V}^{\mathrm{IV}} / \mathrm{V}^{\mathrm{V}}$ Mixed-Valence Alkoxopolyoxovanadium Clusters $\left[\mathrm{V}_{6} \mathrm{O}_{7}(\mathrm{OR})_{12}\right]^{n+}\left(\mathrm{R}=-\mathrm{CH}_{3},-\mathrm{C}_{2} \mathrm{H}_{5}\right)$ : Structural, Cyclovoltammetric and IR-Spectroscopic Investigations on Mixed Valency in a Hexanuclear Core, J. Am. Chem. Soc.127 (2005) 13978-13987.

[18] D. Krstić, M. Colović, N. Bošnjaković-Pavlović, A. Spasojević-de Biré, V. Vasić, Influence of decavanadate on rat synaptic plasma membrane ATPases activity, Gen. Physiol. Biophys. 28 (2009) 302-308

[19] D.L. Stokes, F. Delavoie, W.J. Rice, P. Champeil, D.B. McIntosh, J.J. Lacapère, Structural studies of a stabilized phosphoenzyme intermediate of $\mathrm{Ca}^{2+}$-ATPase, J. Biol. Chem. 280 (2005) 18063-18072.

[20] L.A. Vasilets, W. Schwarz, Structure-function relationships of cation binding in the $\mathrm{Na}+\mathrm{K}(+)-A T P a s e$, Biochim. Biophys. Acta.1154 (1993) 201-222

[21] G. Rodriguez de Lores Arnaiz, C. Peňa, Characterization of synaptosomal membarne Na K ATPase inhibitors, Neurochem. Int. 27 (1995) 319-327.

[22] a) D. Krstić, K. Krinulović, G. Joksić, V. Spasojević - Tisma, T. Momić, V. Vasić, Effects of digoxin and gitoxin on the enzymatic activity and kinetic parameters of Na+/K+-ATPase, J. Enz. Inhib. Med. Chem. 19 (2004) 409-415. b) D. Krstić; K. Krinulović; V. Vasić, Inhibition of Na,K-ATPase and Mg-ATPase by metal ions and prevention and recovery of inhibited activity by chelators, J. Enz. Inhib. Med. Chem. 20 (2005) 469-476. c) J. Z. Blasiak, Cooperative binding of the organophosphate paraoxon to the Na+/K+-ATPase, Naturforsch. 50c (1995) 660-663. 
[23] I. Matsuoka, S.J. Ohkubo, ATP- and adenosine-mediated signaling in the central nervous system: adenosine receptor activation by ATP through rapid and localized generation of adenosine by ecto-nucleotidases, Pharmacol. Sci.94 (2004) 95-99.

[24] G. Scheiner-Bobis, The sodium pump. Its molecular properties and mechanics of ion transport, Eur. J. Biochem. 269 (2002) 2424-33.

[25] F. Lefranc, T. Mijatović, Y. Kondo, S. Sauvage, I. Roland, D. Krstić, V. Vasić, P. Gailly, S. Kondo, G. Blanco, R. Kiss, Targeting the alpha 1 subunit of the sodium pump to combat glioblastoma cells, Neurosurgery 62 (2008) 211-21.

[26] M. Aureliano, Vanadate oligomer inhibition of passive and active $\mathrm{Ca}^{2+}$ translocation by the $\mathrm{Ca}^{2+}$ pump of sarcoplasmic reticulum, J. Inorg. Biochem. 80 (2000) 145-147.

[27] D.W. Boyd, K. Kustin, M. Niwa, Do vanadate polyanions inhibit phosphotransferase enzymes?, Biochim. Biophys. Acta. 827 (1985) 472-47.

[28] a) R.J. Pezza, M.A. Villarreal, G.G. Montich, C.E. Argarana, Vanadate inhibits the ATPase activity and DNA binding capability of bacterial MutS. A structural model for the vanadate-MutS interaction at the Walker A motif, Nucleic Acids Res. 3 (2002) 4700-4708. b) J.M. Messmore, R.T. Raines, Decavanadate inhibits catalysis by ribonuclease A, Arch.Biochem. Biophys. 381 (2000) 25-30.

[29] a) D.C. Crans, M. Mahroof-Tahir, O.P. Anderson, M.M. Miller, X-ray structure of $\left(\mathrm{NH}_{4}\right)_{6}$ (Gly-Gly) $\mathrm{V}_{10} \mathrm{O}_{28} \times 4 \mathrm{H}_{2} \mathrm{O}$. Model studies for polyoxometalates - protein interactions, Inorg. Chem. 33 (1994) 5586-5590. b) K. Stroobants, D. Saadallah, G. Bruylants, T.N. Parac-Vogt, Thermodynamic study of the interaction between hen egg white lysozyme and Ce(IV)-Keggin polyoxotungstate as artificial protease, Phys. Chem. Chem. Phys. 16 (2014) 21778-21787.

[30] M. Aureliano, R.M.C. Gândara, Decavanadate effects in biological systems, J. Inorg. Biochem. 99 (2005) 979-985.

[31] D.L. Stokes, F. Delavoie, W.J. Rice, P. Champeil, D.B. McIntosh, J.J. Lacapère, Structural Studies of a Stabilized Phosphoenzyme Intermediate of $\mathrm{Ca}^{2+}$-ATPase, J. Biol. Chem. 280 (2005) 18063-18072.

[32] T. Tiago, M. Aureliano, C. Gutiérrez-Merino, Decavanadate binding to a high affinity site near the myosin catalytic centre inhibits F-actin-stimulated myosin ATPase activity, Biochemistry. 43 (2004) 555c1-5561.

[33] a) M. Aureliano, Decavanadate contribution to vanadium biochemistry: In vitro and in vivo studies. Inorg. Chimica Acta 420 (2014) 4-7 b) M. Aureliano, C. André Ohlin 
Decavanadate in vitro and in vivo effects: facts and opinions, J. Inorg. Biochem. 137 (2014) 123-130.

[34] N. Bošnjaković-Pavlović, A. Spasojević-de Biré, I. Tomaz, N. Bouhmaida, F. Avecilla, U. Mioc, J. Costa Pessoa, N. E. Ghermani, Electron and electrostatic properties of a cytosine decavanadate compound from high resolution x-ray diffraction: toward a bettter understanding of chemical and biological properties of decavanadates, Inorg. Chem. 48 (2009) 9742-9753.

[35] N. Bošnjaković-Pavlović, J. Prévost, A. Spasojević - de Biré, Crystallographic statistical study of decavanadate anion based structure: toward the prediction of noncovalent interactions, Cryst. Growth \& Des. 11 (2011) 3778-3789.

[36] F. Ping-Ping, W. Xin-Long, W. En-Bo, Q. Chao, X. Lin. Synthesis, Structure Characterization and Biological Activity of a Novel Polyoxovanadate Cluster: $\left[\mathrm{NH}_{3}\left(\mathrm{CH}_{2}\right)_{2} \mathrm{NH}_{2}\left(\mathrm{CH}_{2}\right)_{2} \mathrm{NH}_{3}\right]_{4} \cdot\left[\mathrm{V}_{6} \mathrm{~V}^{\mathrm{IV}}{ }_{12} \mathrm{O}_{42}\left(\mathrm{PO}_{4}\right)\right]\left(\mathrm{PO}_{4}\right) \cdot 2 \mathrm{H}_{2} \mathrm{O}$, Chem. Res. Chinese. 21(4)(2005) 381-385.

[37] T. Yamase, Medical chemistry of polyoxometalates. Part 1. Potent antitumor activity of polyoxomolybdates on animal transplantable tumorsand human cancer xenograft, Inorg Chim Acta 15 (1988) 15-8.

[38] T. Yamase, Polyoxometalates for molecular devices: antitumor activity and luminescence, Mol. Eng. 3 (1993) 241-62.

[39] H. Yanagie, A. Ogata, S. Mitsui, T. Hisa, T. Yamase, M. Eriguchi, Anticancer activity of polyoxomolybdate, Biomed. Pharmacother. 60 (2006) 349-352.

[40] F.H. Allen, The Cambridge Structural Database: a quarter of a million crystal structures and rising, Acta Cryst.B58 (2002) 380-388.

[41] (a) T. Steiner, The hydrogen bond in the solid state, Angew. Chem. Int. Ed. 41 (2002) 4976. (b) R. Taylor, O. Kennard, Crystallographic evidence for the existence of C-H...O, C-H....N, and C-H...Cl hydrogen bonds, J. Am. Chem. Soc. 104 (1982) 5063-5070.

[42] a) G.R. Desiraju, The $\mathrm{C}-\mathrm{H} \cdots \mathrm{O}$ Hydrogen Bond: Structural Implications and Supramolecular Design, Acc. Chem. Res. 29 (1996) 441-449. b) G.R. Desiraju, T. Steiner, The weak hydrogen bond in structural chemistry and biology, Oxford University Press, 1999

[43] G. Bogdanović, A. Spasojević-de Biré, S. Zarić, Evidence of a C-H... $\pi$ interaction between an organic moiety and a chelate ring in transition metal complexes based on crystal structures and computations, Eur. J. Inorg. Chem. 7 (2002) 1599-1602. 
[44] H.M. Berman, M.J. Gabanyi, R. Colin, Groom, J.E. Johnson, G.N. Murshudov, R.A. Nicholls, V. Reddy, T. Schwede, M.D. Zimmerman, J. Westbrooka, W. Minorg, Data to knowledge: how to get meaning from your result, IUCrJ 2 (2015) 45-58.

[45] P.Wu, J.Chen, P.Yin, Z.Xiao, J.Zhang, A.Bayaguud, Y.Wei, Solvent induced supramolecular chiralityswitching of bis (trisalkoksy) hexavanadate, Polyhedron 52 (2013) 1344-1348.

[46] P. Wu, Z. Xiao, J. Zhang, J. Hao, J. Chen, P. Yin, Y. Wei, DMAP catalyzed esterification of pentaerythritol derivatized POMs: a new route for the functionalization of polyoxometalates, Chem.Commun. 47 (2011) $5557-5559$.

[47] V. Vasić, D. Jovanović, D. Krstić, G. Nikezić, A. Horvat, L. Vujisić, N. Nedeljković, Prevention and recovery of $\mathrm{CuSO}_{4}$ induced inhibition of $\mathrm{Na}, \mathrm{K}$-ATPase and Mg-ATPase in rat brain synaptosomes by EDTA, Toxicol. Lett.110 (1999) 95-104.

[48] (a) M.P. Santoni, A.K. Pal, G.S. Hanan, M.C. Tang, K. Venne, A. Furtos, P. Ménard Tremblay, C. Malveauand, B. Hasenknopf, Coordination-driven self-assembly of polyoxometalates into discrete supramolecular triangles, Chem. Commun. 48 (2012) 200-202. (b) M.P. Santoni, A.K. Pal, G.S. Hanan, A. Proust, B. Hasenknopf, Discrete covalent organic-inorganic hybrids: terpyridine functionalized polyoxometalates obtained by a modular strategy and their metal complexation, Inorg Chem. 50 (14) (2011) 6737-45. (c) P. Wu, Z. Xiao, J. Zhang, J. Hao, J. Chen P. Yin, Y. Wei, DMAPcatalyzed esterification of pentaerythritol-derivatized POMs: a new route for the functionalization of polyoxometalates, Chem. Commun. 47 (2011) 5557-5559. (d) D. Li, J. Song, P. Yin, S. Simotwo, A.J. Bassler, Y.Y. Aung, J.E. Roberts, K.I. Hardcastle, C.L .Hill, Tianbo Liu, Inorganic-Organic Hybrid Vesicles with Counterion- and pHControlled Fluorescent Properties, J.Am.Chem.Soc.133 (2011) 14010-14016. (e) C. A. S. Favette, L.M. Chamoreau, J. Vaissermann, L. Ruhlmann' B. Hasenknopf, Hybrid Organic-Inorganic Porphyrin-Polyoxometalate Complexes, Eur. J. Inorg. Chem. 2008(22) (2008) 3433-3441.(f) Q. Chen, J.A. Zubieta, Structural investigation of the hexavanadate core in oxidized,mixed valence and reduced clasters of the type $\left[\mathrm{V}_{6-} \mathrm{n}\right.$ $\left.\mathrm{V}_{\mathrm{n}}^{\mathrm{Iv}} \mathrm{O}_{13-\mathrm{n}}(\mathrm{OH})_{\mathrm{S}}\left\{\left(\mathrm{OCH}_{2}\right)_{3} \mathrm{CR}\right\}_{2}\right]^{2} \mathrm{n}=0.3 .6$, Inorg Chim Acta 95 (1992) 198-200.

[49] (a) E. Scales, L. Sorace, A. Dei, A. Caneschi, C.A. Muryn, D. Collison, E.J.L. McInnes, Chemical Science 1 (2010) 221-225. (b) C. Daniel, H. Hartl, A mixed-valence $\mathrm{V}(\mathrm{IV}) / \mathrm{V}(\mathrm{V})$ alkoxo-polyoxovanadium cluster series $\left[\mathrm{V}_{6} \mathrm{O}_{8}\left(\mathrm{OCH}_{3}\right)_{11}\right] \mathrm{n}+/-$ : exploring the influence of a mu-oxo ligand in a spin frustrated structure, 131 (2009) 5101-5114. (c) C. 
Aronica, G. Chastanet, E. Zueva, S.A. Borshch, J. M. Clemente-Juan, D. Luneau, A polyoxoalkoxovanadium (III, IV) with a calixarene macrocyle crown. A first example of mixed-valence vanadium (III, IV), J. Am. Chem. Soc. 130 (2008) 2365-2371. (d) M.A. Augustyniak-Jabłokow, S. Borshch, C. Daniel, H. Hartl, Y.V. Yablokov, EPR study of the magnetic states of a mixed-valence $\mathrm{V}^{\mathrm{IV}}{ }_{4} \mathrm{~V}_{2}$ alkoxypolyox vanadium cluster, New $\mathrm{J}$. Chem. 29 (2005) 1064-1071. (e) C. Daniel, H. Hartl, Neutral and cationic V(IV)/V(V) mixed-valence alkoxo-polyoxovanadium clusters $\left[\mathrm{V}_{6} \mathrm{O}_{7}(\mathrm{OR})_{12}\right] \mathrm{n}+\left(\mathrm{R}=-\mathrm{CH}_{3},-\mathrm{C}_{2} \mathrm{H}_{5}\right)$ : structural, cyclovoltammetric and IR-spectroscopic investigations on mixed valency in a hexanuclear core, J. Am. Chem. Soc. 127 (2005) 13978-87. (f) J. Spandl, C. Daniel, I. Brüdgam, H. Hartl, Synthesis and Structural Characterization of Redox-Active Dodecamethoxoheptaoxohexavanadium Clusters, Angew. Chem. Int. Ed. Engl. 42 (2003) 1163-1166.

[50] M.J. Frisch, G.W. Trucks, H.B. Schlegel, G.E. Scuseria, M.A. Robb, J.R. Cheeseman, G. Scalmani, V. Barone, B. Mennucci, G.A. Petersson, H. Nakatsuji, M. Caricato, X. Li, H.P. Hratchian, A.F. Izmaylov, J. Bloino, G. Zheng, J.L. Sonnenberg, M. Hada, M. Ehara, K. Toyota, R. Fukuda, J. Hasegawa, M. Ishida, T. Nakajima, Y. Honda, O. Kitao, H. Nakai, T. Vreven, J.A. Montgomery, J.E. Peralta, F. Ogliaro, M. Bearpark,J.J. Heyd, E. Brothers, K.N. Kudin, V.N. Staroverov, T. Keith, R. Kobayashi, J. Normand, K. Raghavachari, A. Rendell, J.C. Burant, S.S. Iyengar, J. Tomasi, M. Cossi, N. Rega, J.M. Millam, M. Klene, J.E. Knox, J.B. Cross, V Bakken, C. Adamo, J. Jaramillo, R. Gomperts, R.E. Stratmann, O. Yazyev, A.J. Austin, R. Cammi, C. Pomelli, W.J. Ochterski, R.L. Martin, K. Morokuma, V.G.. Zakrzewski, G..A. Voth, P. Salvador, J.J. Dannenberg, S. Dapprich, A.D. Daniels, O. Farkas, J.B. Foresman, J.V. Ortiz, J. Cioslowski, D.J. Fox Gaussian, Inc., Wallingford CT, 2010.

[51] a) A.D.J. Becke, Density functional thermochemistry. III. The role of exact exchange, Chem. Phys. 98 (1993) 5648-5652 b) Y. Zhao, D.G. Truhlar, The M06 suite of density functionals for main group thermochemistry, thermochemical kinetics, noncovalent interactions, excited states, and transition elements: two new functionals and systematic testing of four $\mathrm{MO}_{6}$-class functionals and 12 other functionals, Theor. Chem. Acc. 120 (2008) 215-41 c) J.P. Perdew, Density-functional approximation for the correlation energy of the inhomogeneous electron gas, Phys. Rev. B33 (1986) 8822-8824.

[52] a)V.A. Rassolov, M.A. Ratner, J.A. Pople, P.C. Redfern, L.A. Curtiss, 6-31G* basis set for third-row atoms, J. Comp. Chem. 22 (2001) 976-984 b) R.C. Binning, L.A. Curtiss, 
Compact contracted basis sets for third-row atoms: Ga-Kr, J. Comp. Chem. 11 (1990) 1206-1216.c) T.H.Jr. Dunning, Gaussian Basis Sets for Use in Correlated Molecular Calculations. I. The Atoms Boron Through Neon and Hydrogen, J. Chem. Phys. 90 (1989) 1007-1023.

[53] X. Xu, "Experimental and theoretical charge density analysis of functionalized polyoxovanadates: toward a better understanding of chemical bonding and chemical reactivity", 2015, PhD thesis. Ecole Centrale Paris, 2015. English

[54] M.I. Khan, Q. Chen, J. Zubieta, D.P. Goshorn, Hexavanadium polyoxoalkoxide anion clusters: structures of the mixed-valence species $\left(\mathrm{Me}_{3} \mathrm{NH}\right)\left[\right.$ VIV5 $\left.5 V \mathrm{VV}_{7}(\mathrm{OH})_{3}\left\{\mathrm{CH}_{3} \mathrm{C}\left(\mathrm{CH}_{2} \mathrm{O}\right)_{3}\right\}_{3}\right]$ and of the reduced complex $\mathrm{Na}_{2}\left[\mathrm{VIV}_{6} \mathrm{O}_{7}\left\{\mathrm{CH}_{3} \mathrm{CH}_{2} \mathrm{C}\left(\mathrm{CH}_{2} \mathrm{O}\right)_{3}\right\}\right.$ 4], Inorg. Chem. 31(9) (1992)1556-1558.

[55] A. Müller, J. Meyer, H. Bogge, A. Stammler, A.Y. Botar, Cis-/Trans-Isomerie bei Bis(trisalkoxy)-hexavanadaten - Cis- $\mathrm{Na}_{2}\left[\mathrm{~V}-6(\mathrm{IV}) \mathrm{O}-7(\mathrm{OH})_{6}\left(\left(\mathrm{OCH}_{2}\right)(3) \mathrm{CCH}_{2} \mathrm{OH}\right)_{2}\right) \cdot 8 \mathrm{H}_{2} \mathrm{O}$, cis- $\left(\mathrm{CN}_{3} \mathrm{H}_{6}\right) 3\left[\mathrm{~V}-5(\mathrm{IV}) \mathrm{O}-\mathrm{V}_{13}\left(\left(\mathrm{OCH}_{2}\right)_{3} \mathrm{CCH}_{2} \mathrm{OH}\right)_{2}\right] \cdot 4,5 \mathrm{H}_{2} \mathrm{O}$ und trans- $\left(\mathrm{CN}_{3} \mathrm{H}_{6}\right)_{2}[\mathrm{~V}-$ 6(V)O-13( $\left.\left.\left(\mathrm{OCH}_{2}\right)_{3} \mathrm{CCH}_{2} \mathrm{OH}\right)_{2}\right] \cdot \mathrm{H}_{2} \mathrm{O}$, Anorg. Allg. Chem. 621 (1995) 1818-1831.

[56] A.J. Ziegler, J. Florian, M.A. Ballicora, A.W. Herlinger, Alcaline phosphatase inhibition by vanadilếbdiketone complexes:electron density effects, J. Enzyme Inhib. Med. Chem. 24 (2009) 22-28.

[57] M.H. Kathleen M, B. Stec, E. R. Kantrowitz, A Model of the Transition State in the Alkaline Phosphatase Reaction, J. Biol. Chem. 274 (1999) 8351-8354.

[58] L.R. Felts, J.T. Reilly, J.J. Tanner Structure of Francisella tularensis AcpA: prototype of a unique superfamily of acid phosphatases and phospholipases J. Biol. Chem. 281 (2006) 30289-30298.

[59] J.H. Bae, E.D. Lew, S. Yuzawa, F. Tome, I. Lax, J. Schlessinger, The selectivity of receptor tyrosine kinase signaling is controlled by a secondary $\mathrm{SH} 2$ domain binding site.Cell (Cambridge, Mass.) 138 (2009) 514-524.

[60] J. Schulz, R. Gyepes, I. Císařová, P. Štěpnička, Synthesis, structural characterisation and bonding in an anionic hexavanadate bearing redox-active ferrocenyl groups at the periphery, New J. Chem. 34 (2010) 2749-2756.

\section{List of Figures}

Figure 1 Labeling scheme and type of atoms in the functionalized V6 ion. (a) Structure of functionalized V6 anion; (b) Atomic surroundings of V atom. 
Figure 2. The influence of various concentrations of hexavanadates 1-5 on the activity of commercially available, purified porcine cerebral cortex $\mathrm{Na}^{+} / \mathrm{K}^{+}$-ATPase. The residual enzyme activity is expressed as a percent of the control value (the enzyme activity obtained in the absence of the inhibitor). The values are expressed as mean \pm S.E.M. The plots of experimental values are fitted by sigmoidal functions.

Figure 3. Theoretical electrostatic potential (EP) $\left(\mathrm{e} . \AA^{-1}\right)$ mapped on isodensity surface $(0.007$ e. $\left.\mathrm{A}^{-3}\right)$ (second column) and isosurface of theoretical electrostatic potential (EP) (e. $\left.\AA^{-1}\right)$ for $\left[\mathrm{V}_{6} \mathrm{CH}_{3}\right],\left[\mathrm{V}_{6} \mathrm{NO}_{2}\right],\left[\mathrm{V}_{6} \mathrm{OH}\right]$ and $\left[\mathrm{V}_{6}-\mathrm{C}_{3}\right]$. First column: molecular structure.

Figure 4. Theoretical EP values $\left(e \AA^{-1}\right)$ at the molecular surface for $V_{10}$ and for the functionalized $V_{6}$ series.

Figure 5. Distribution of distances and angles for $\mathrm{CH}$...O interactions according to the different oxygen types in the CSD V6 series from table 1.

Figure 6. a) Distribution of the C-H...O distances b) Distribution of the value of the C-H..O angles in the CSD V6 series from table 1.

\section{List of Tables}

Table 1. List of arm-like functionalized V6 used in this paper. The number of non-covalent interactions (NCI) is given in the last column. In Parentheses the NCI number concerning the $\mathrm{O} 1 \mathrm{x}$ (respectively $\mathrm{O} 2 \mathrm{x}$ in bold).

Table 2. List of $\mathrm{V}_{6}$ bridged with more than six organic ligands.

Table 3 Inhibition parameters $\left(\mathrm{IC}_{50}\right.$ values $(10 \mathrm{~min})$ for $\mathrm{V}_{6}$ of commercially purified $\mathrm{Na}^{+} / \mathrm{K}^{+}$ATPase. The size of the anion, modeled by the longest distance between opposite atoms of the organic part is given. $\mathrm{V}_{10}$ : decavanadate $\left[\mathrm{V}_{10} \mathrm{O}_{28}\right]^{6-}$. 


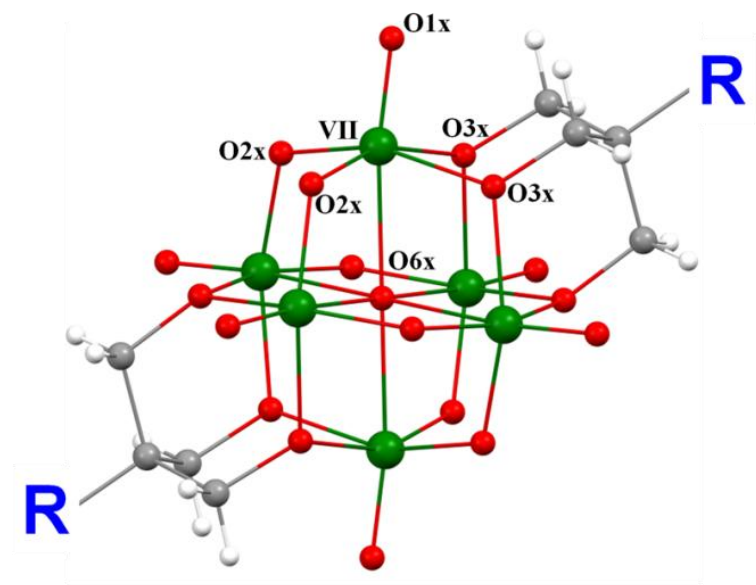

(a)

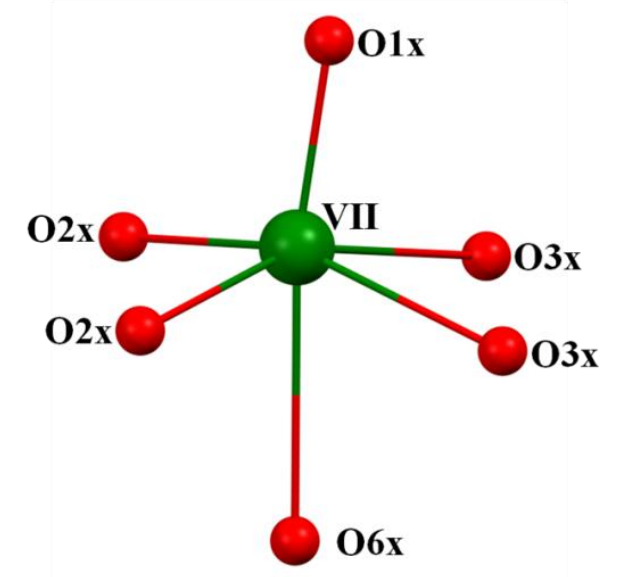

(b)

Figure 1 


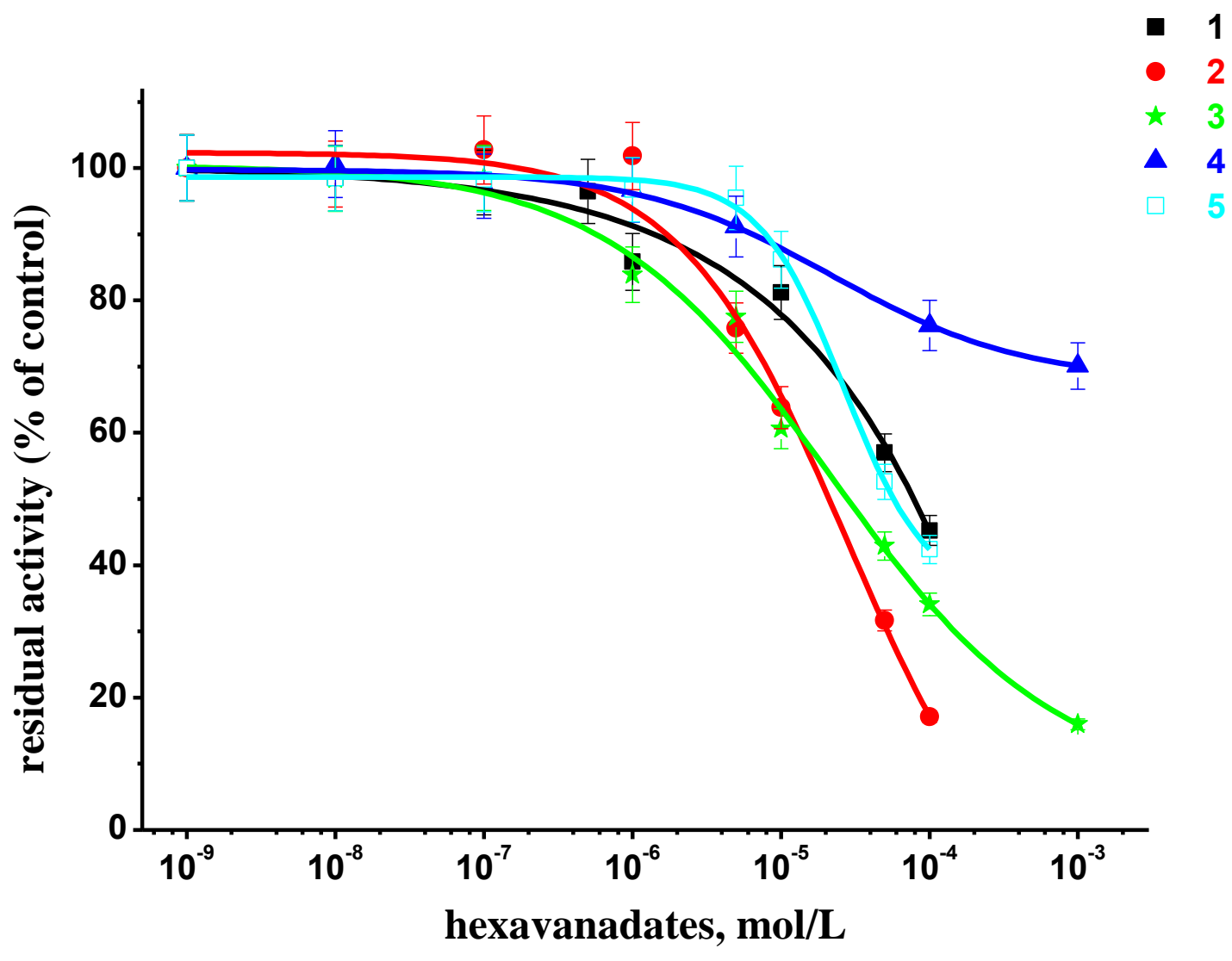

Figure 2. 

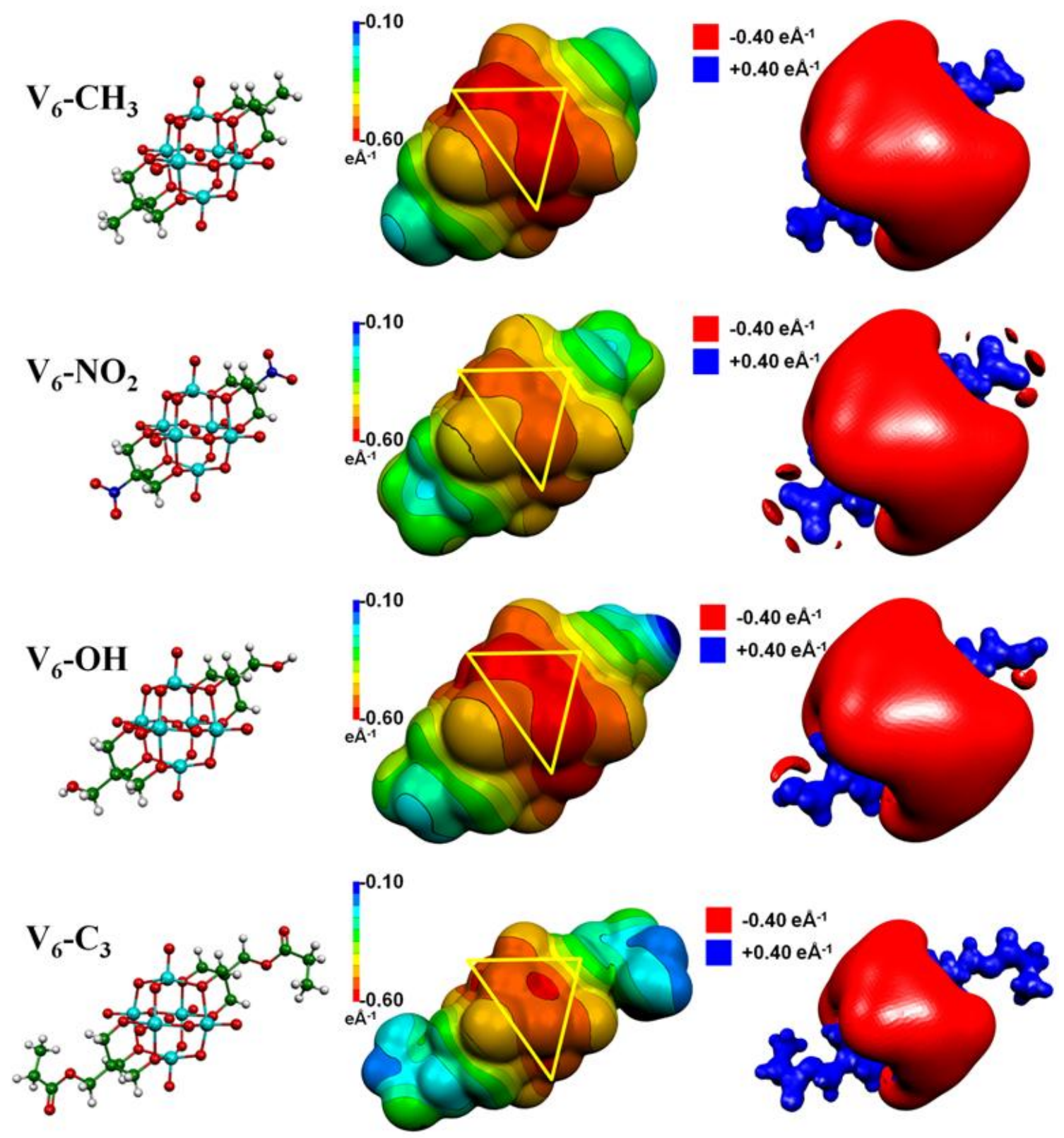

Figure 3. 


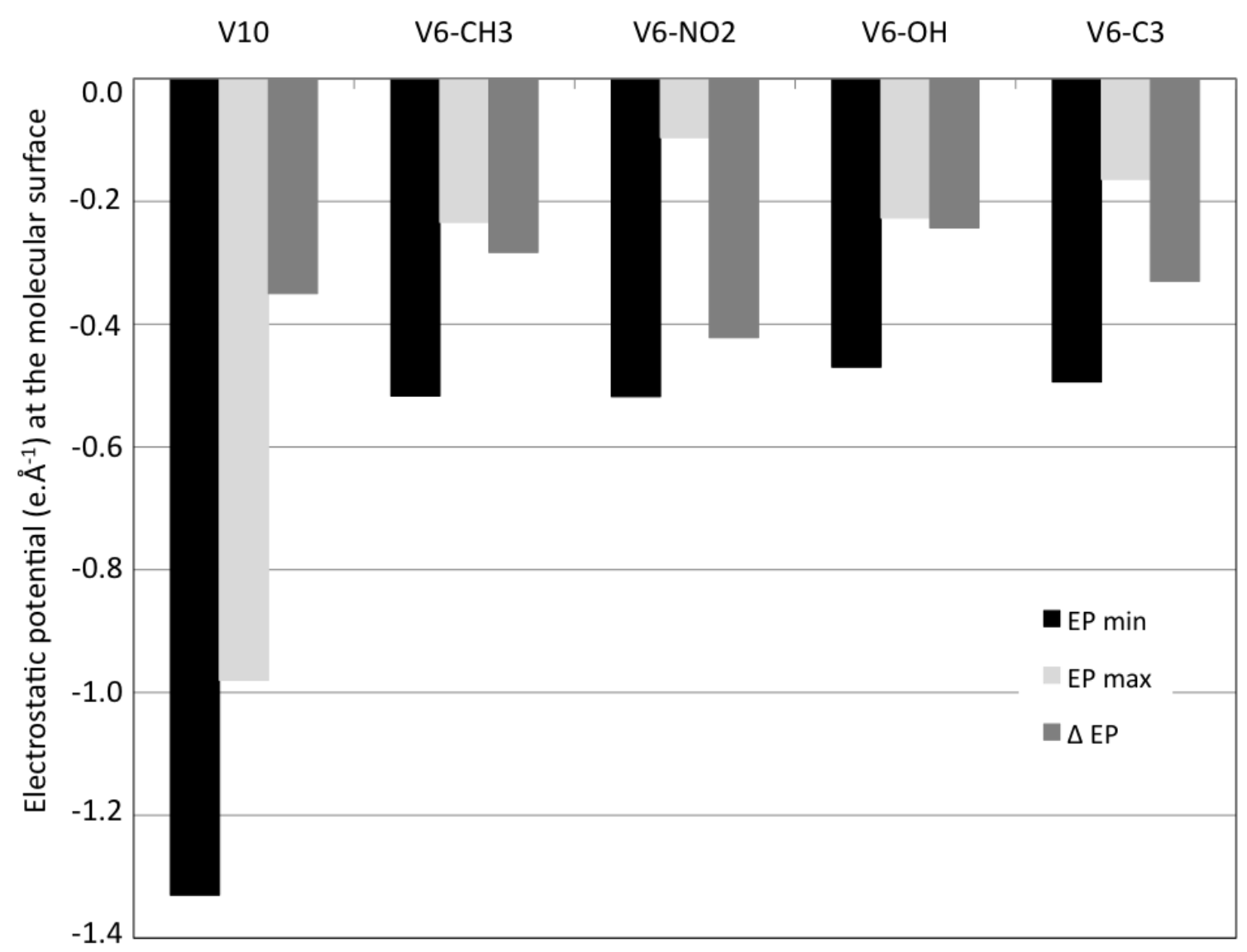

Figure 4. 


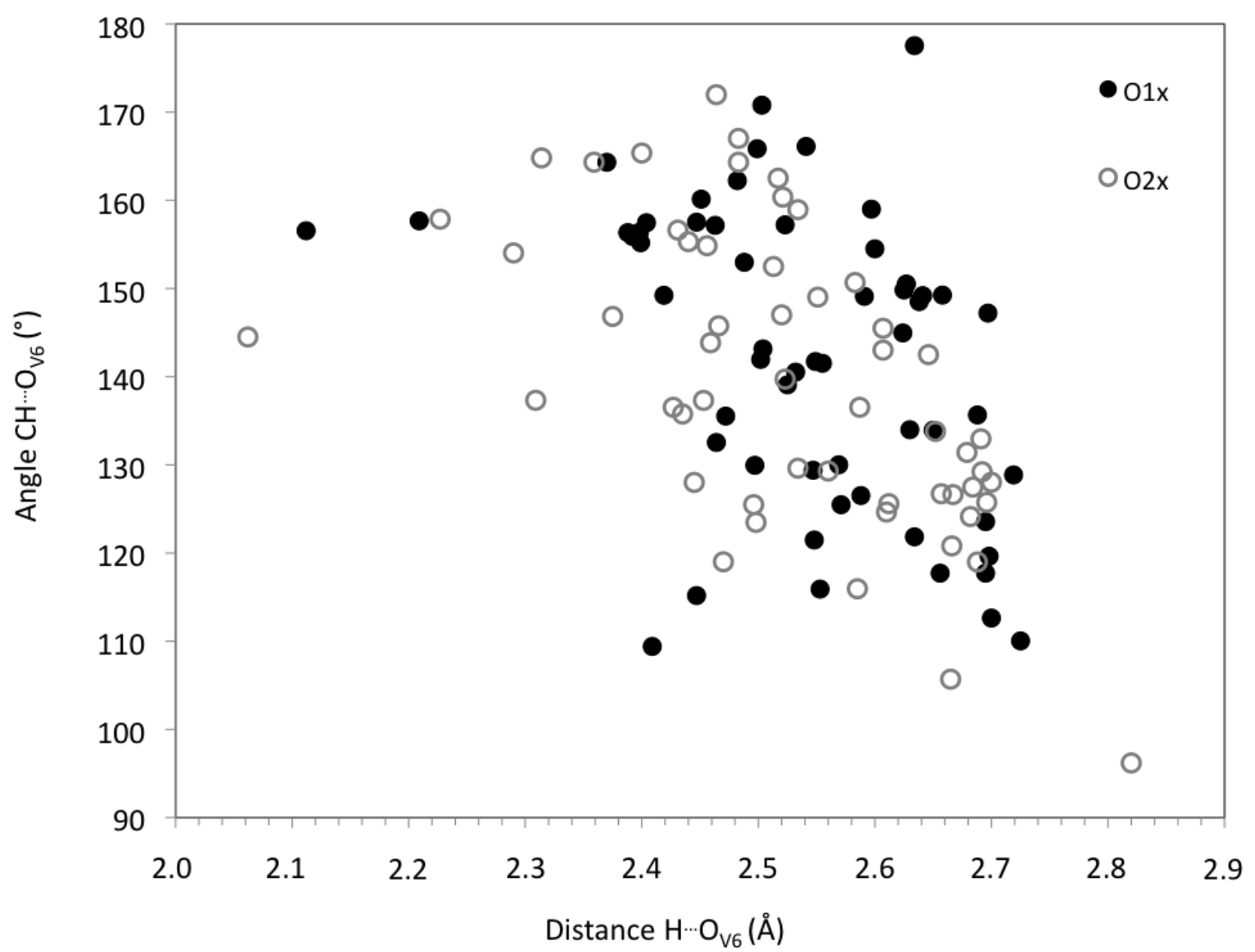

Figure 5. 


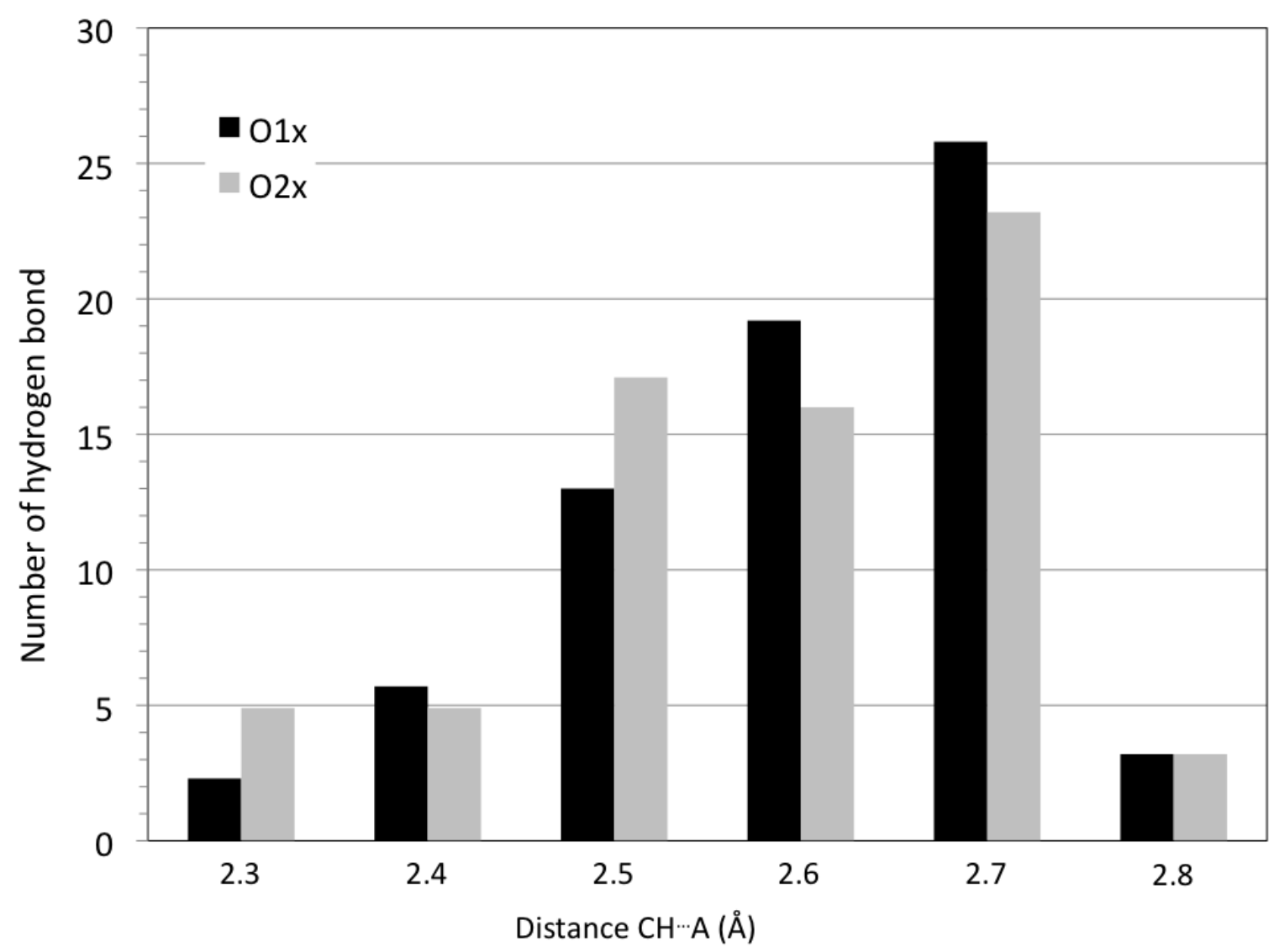

Figure 6. a 


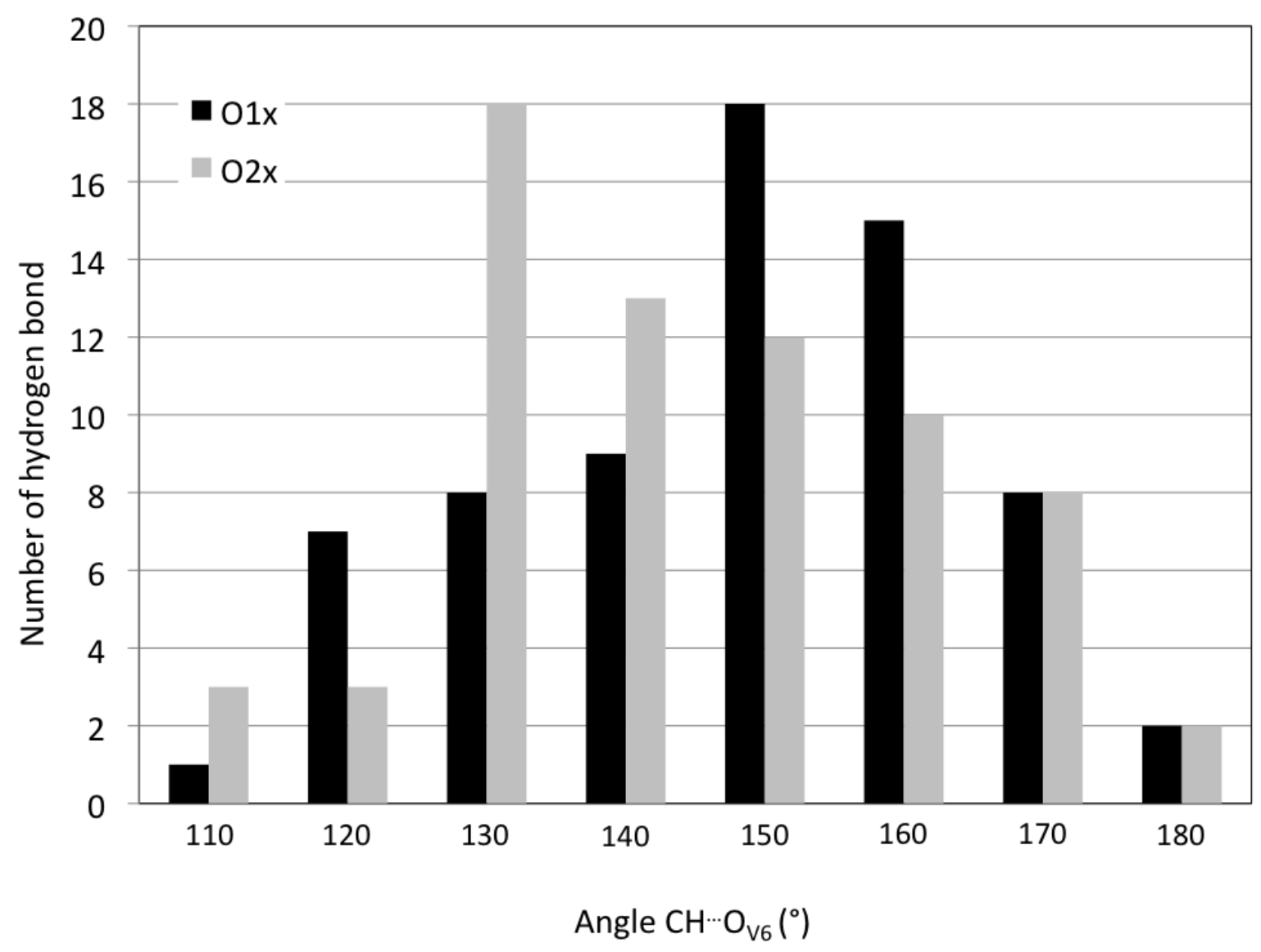

Figure 6. b 
Table 1.

\begin{tabular}{|c|c|c|c|c|c|}
\hline Refcode & $\begin{array}{c}\text { Structure of functionalized } \\
\text { Hexavanadate }\end{array}$ & $\begin{array}{c}\mathbf{R} \\
\text { factor }\end{array}$ & $\begin{array}{c}\text { Cation or other } \\
\text { segment }\end{array}$ & Reference & $\begin{array}{c}\text { Total number } \\
\text { of NCI } \\
(01 x / 02 x)\end{array}$ \\
\hline \multicolumn{6}{|c|}{ Non-protonated $\mathrm{V}_{6}$} \\
\hline EGEMUZ & & 7.7 & $\mathrm{TBA}^{+}$ & $48 \mathrm{e}$ & $10(6 / 4)$ \\
\hline EGENEK & & 8.75 & $\begin{array}{c}\mathrm{TBA}^{+} \\
\mathrm{CH}_{3} \mathrm{CN}\end{array}$ & $48 \mathrm{e}$ & $7(2 / 5)$ \\
\hline LOFVUY & & 8.79 & $\begin{array}{c}\mathrm{Tb}^{2+} \\
\left(\mathrm{CH}_{3}\right)_{2} \mathrm{NCHO}\end{array}$ & 12 & $6(3 / 3)$ \\
\hline NEMDEP & & 6.74 & $\begin{array}{c}\mathrm{TBA}^{+} \\
\mathrm{N}\left(\mathrm{CH}_{3}\right)_{2} \mathrm{CHO}\end{array}$ & 11 & $7(1 / 6)$ \\
\hline NEMDIT & & 7.78 & $\begin{array}{c}\mathrm{Co}^{2+} \\
\mathrm{N}\left(\mathrm{CH}_{3}\right)_{2} \mathrm{CHO}\end{array}$ & 11 & $8(7 / \mathbf{1})$ \\
\hline NEMDOZ & & 9.76 & $\begin{array}{c}\mathrm{Mn}^{2+} \\
\mathrm{N}\left(\mathrm{CH}_{3}\right)_{2} \mathrm{CHO}\end{array}$ & 11 & $5(4 / 1)$ \\
\hline NEMDUF & & 9.73 & $\begin{array}{c}\mathrm{Ni}^{2+} \\
\mathrm{N}\left(\mathrm{CH}_{3}\right)_{2} \mathrm{CHO}\end{array}$ & 11 & $5(4 / 1)$ \\
\hline NEMFAN & & 8.98 & $\begin{array}{c}\mathrm{Zn}^{2+} \\
\mathrm{N}\left(\mathrm{CH}_{3}\right)_{2} \mathrm{CHO}\end{array}$ & 11 & $9(5 / 4)$ \\
\hline OQETOU & & 5.76 & $\mathrm{TBA}^{+}$ & $48 \mathrm{c}$ & $6(3 / 3)$ \\
\hline OQETUA & & 4.13 & $\mathrm{TBA}^{+}$ & $48 \mathrm{c}$ & $6(1 / 5)$ \\
\hline PELYIO & & 6.62 & $\mathrm{TBA}^{+}$ & 14 & $8(1 / 7)$ \\
\hline SAJWEH & & 7.81 & $\mathrm{CH}_{3} \mathrm{SOCH}_{3}$ & $48 \mathrm{~d}$ & $3(2 / \mathbf{1})$ \\
\hline
\end{tabular}




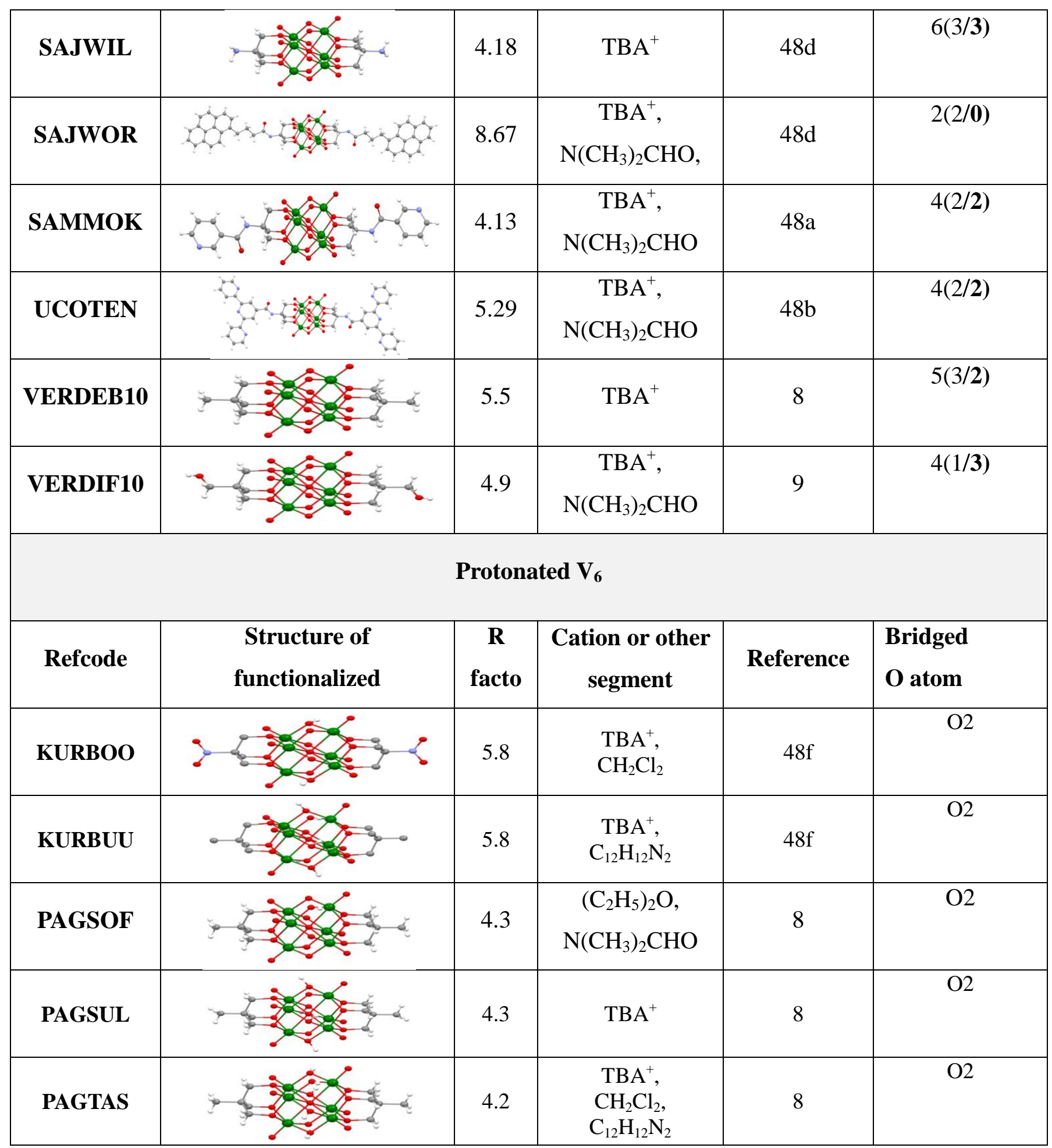


Table 2.

\begin{tabular}{|c|c|c|c|c|}
\hline Refcode & $\begin{array}{c}\text { Structure of } \\
\text { functionalized } \\
\text { Hexavanadate }\end{array}$ & $R$ factor & $\begin{array}{c}\text { Cation or other } \\
\text { segment }\end{array}$ & Reference \\
\hline FUSLEL & & 3.18 & - & $48 \mathrm{e}$ \\
\hline MUXTAA & & 4.24 & - & $48 \mathrm{e}$ \\
\hline MUXTAА01 & & 2.82 & - & 12 \\
\hline MUXTAA02 & & 2.82 & - & 11 \\
\hline MUXTEE & & 7.36 & $\begin{array}{c}\mathrm{TBA}^{+} \\
\mathrm{CH}_{3} \mathrm{OH}\end{array}$ & 11 \\
\hline MUXTOO & & 4.37 & $\mathrm{TBA}^{+}$ & 11 \\
\hline NOBDAK & & 5.18 & $\mathrm{Et}_{4} \mathrm{~N}^{+}$ & 11 \\
\hline NOBDEO & & 7.38 & $\mathrm{NH}_{4}^{+}$ & 11 \\
\hline NOBDIS & & 5.04 & $\left(\mathrm{C}_{2} \mathrm{H}_{5}\right)_{3} \mathrm{NH}^{+}$ & $48 \mathrm{c}$ \\
\hline NOBDOY & & 5.75 & $\mathrm{C}_{5} \mathrm{H}_{6} \mathrm{~N}^{+}$ & $48 \mathrm{c}$ \\
\hline QAWDUO & & 3.59 & $\mathrm{SbCl}_{6}^{-}$ & 14 \\
\hline XADMEU01 & & 4.94 & - & $48 \mathrm{~d}$ \\
\hline MUVLUL & & 7.24 & $\begin{array}{c}\mathrm{CH}_{3} \mathrm{OH} \\
\mathrm{H}_{2} \mathrm{O}\end{array}$ & $48 d$ \\
\hline
\end{tabular}


Table 3

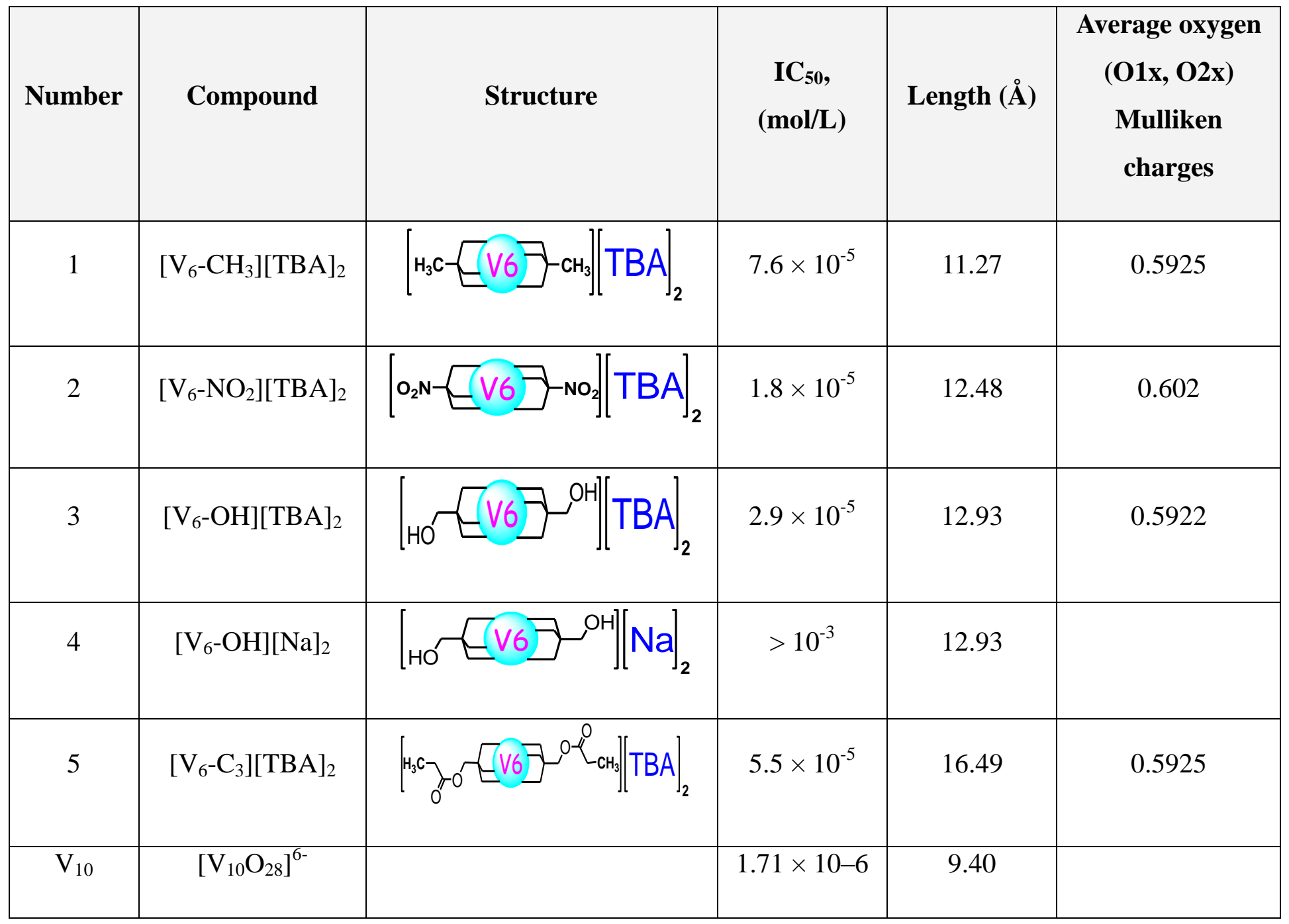

